The Peter A. Allard School of Law

Allard Research Commons

Transnational Business Governance

Interactions Working Papers

Working Paper Series

2013

Private Governance, Public Implications and the Tightrope of Regulatory Reform: The ISDA Credit Derivatives Determinations Committees

John Biggins

Colin Scott

Follow this and additional works at: https://commons.allard.ubc.ca/tbgi

Part of the Business Law, Public Responsibility, and Ethics Commons, Business Organizations Law Commons, Finance and Financial Management Commons, International Business Commons, and the Transnational Law Commons 


\section{OSGOODE}

OSCOODE HALL LAW SCHOOL

YOR K UNIVERSITY

\section{OSGOODE HALL LAW SCHOOL \\ Comparative Research in Law \& Political Economy}

RESEARCH PAPER SERIES

Research Paper No. 57/2013

TBGI Project Subseries No.17

\section{Private Governance, Public Implications and the Tightrope of Regulatory Reform: The ISDA Credit Derivatives Determinations Committees}

John Biggins and Colin Scott

\section{Editors:}

Peer Zumbansen (Osgoode Hall Law School, Toronto, Director Comparative Research in Law and Political Economy)

John W. Cioffi (University of California at Riverside)

\section{The TBGI Project}

Transnational initiatives to regulate business activities interact increasingly with each other and with official regulation, generating complex governance ensembles. Heterogeneous actors and institutions interact at multiple levels and in various ways, from mimicry and cooperation to competition and conflict. The TBGI Project investigates the forms, drivers, mechanisms, dynamics, outputs and impacts of transnational business governance interactions (TBGI) from diverse theoretical and methodological perspectives. It is funded by a Social Sciences and Humanities Research Council of Canada grant led by Professor Stepan Wood, Osgoode. 


\title{
Private Governance, Public Implications and the Tightrope of Regulatory Reform: The ISDA Credit Derivatives Determinations Committees*
}

\author{
John Biggins $^{* *}$ and Colin Scott ${ }^{* * *}$
}

\begin{abstract}
Regulatory relationships in financial markets exemplify the importance and changing nature of transnational business governance interactions (TBGI). These interactions involve reciprocal forces of influence between private and public regulators. This paper examines one key case of private governance in financial markets: the emergence, structures and decision-making of Credit Derivatives Determinations Committees (DCs) of the International Swaps and Derivatives Association (ISDA). The paper highlights the mechanisms or 'pathways' of interaction between ISDA, governments, courts and public regulators. Interactions between state and non-state actors are shown to occur in both operational and policy spheres. ISDA is found to be a particularly resilient private regulator in an environment subject both to the significant external shock of the global financial crisis and intense pressure on governmental actors to demonstrate that they are counteracting risk. The reasons behind ISDA's adaptive capacities are considered.
\end{abstract}

Keywords: Derivatives, Private Governance, Regulatory Reform

JEL Classifications: D78 (Analysis of Collective Decision-Making: Positive Analysis of Policy-Making and Implementation); F36 (International Finance: Financial Aspects of Economic Integration); G38 (Corporate Finance and Governance: Government Policy and Regulation); L51 (Regulation and Industrial Policy: Economics of Regulation)

\footnotetext{
${ }^{*}$ This article is based on a paper presented to the $6{ }^{\text {th }}$ European Consortium for Political Research (ECPR) General Conference at the University of Iceland, Reykjavik, 25-27 August 2011. We are grateful to participants for comments. We are especially grateful to James Perry and Tony Porter for their feedback on that earlier paper. We are also grateful also to Frank Partnoy and Stepan Wood for comments on this draft article. We, of course, remain responsible for all errors and infelicities. The earlier paper and, ultimately, this article derives from a broader research initiative: 'Transnational Private Regulation in the OTC Derivatives Industry' which the authors were involved in as part of an international collaboration funded by the Hague Institute for the Internationalisation of Law and coordinated by Fabrizio Cafaggi at the European University Institute: Constitutional Foundations of Transnational Private Regulation. Views expressed in this chapter are the personal views of the authors alone and do not necessarily represent the views of any other individuals or organisations to which the authors are affiliated. Errors and omissions are also the authors' alone. This chapter was largely drafted in early April 2013 and is not reflective of subsequent developments.

** B.A. (Hons); LL.M; UCD Centre for Regulation and Governance. E: bigginsj@tcd.ie

${ }^{* * *}$ Dean of Law and Professor of EU Regulation \& Governance, University College Dublin. E: colin.scott@ucd.ie
} 


\section{Introduction: Context of Private Power in Financial Markets}

Markets for financing personal, corporate and governmental activity became a central feature of economic life in the industrial and post-industrial age. During the last quarter of the twentieth century, measures of liberalization in regulatory oversight of those markets were accompanied by a heightened degree of complexity in transactions, as banks and other entities increasingly deployed a wider range of instruments and operated across national borders. A conjunction of factors related to these trends culminated in the global financial crisis (GFC) of 2007-2008 and, arguably, a continuing banking and fiscal crisis within the Eurozone. ${ }^{1}$

The nature and appropriateness of both governmental and business power in the governance arrangements for these markets is contested. To those who argued that light touch regulation of financial markets tended to remove the state from a key role, there is a reminder that state activity is necessarily constitutive of private market activity generally; and in financial markets in particular. ${ }^{2}$ Those who blamed the GFC on excessive dependence on self-regulation, and expected private governance to be replaced with public regulation at every turn have had their expectations defied. There is evidence of the continuing importance of private regulation across key aspects of financial behaviour. Hence, the relationship between businesses and governments in the regulation of transnational financial markets has changed, but not necessarily with the effect of excluding businesses and their associations from regulatory roles. ${ }^{3}$

The GFC has shown up and demanded greater scrutiny of private governance arrangements, and also created a dynamic within which certain of these arrangements have been questioned. There has thus been a degree of movement towards greater governmental and inter-governmental activity in indirect monitoring of private regulation, as well as direct regulation of markets; notably over-thecounter (OTC) derivatives. ${ }^{4}$ Accordingly, this has resulted in a substantial re-engagement of public supervisory authorities with these financial instruments; including, for instance, the Commodity Futures Trading Commission (CFTC) $)^{5}$ and Securities and Exchange Commission (SEC) ${ }^{6}$ in the US, as well as the European Commission ${ }^{7}$ and Supervisory Authorities (ESAs) ${ }^{8}$ in the EU. Public authorities

\footnotetext{
${ }^{1}$ See, e.g., A. Mody and D. Sandri, The Eurozone Crisis: How Banks and Sovereigns Came to be Joined at the Hip (IMF Working Paper 11/269, November 2011): available online at http://www.imf.org/external/pubs/ft/wp/2011/wp11269.pdf; R. Martin, 'The Local Geographies of the Financial Crisis: From the Housing Bubble to Economic Recession and Beyond' (2011) 11 Journal of Economic Geography 587; L. Story, L. Thomas and N.D. Schwartz, 'Wall St. Helped to Mask Debt Fuelling Europe's Crisis', New York Times (13 February 2010); B. Balzli, 'How Goldman Sachs Helped Greece to Mask Its True Debt', Spiegel Online International (2 August 2010): available at http://www.spiegel.de/international/europe/greekdebt-crisis-how-goldman-sachs-helped-greece-to-mask-its-true-debt-a-676634.html.

${ }^{2}$ C. Shearing, 'A Constitutive Conception of Regulation' in Business Regulation in Australia's

Future, eds J. Braithwaite and P. Grabosky (Canberra: Australian Institute of Criminology, 2003); L. Rethel and T. Sinclair, The Problem with Banks (London: Zed Books, 2012).

${ }^{3}$ See, e.g., A. Nölke and J. Perry, 'The Power of Transnational Private Governance: Financialization and the IASB' (2007) 9 Business and Politics (Article 4).

${ }^{4}$ See, e.g., S. Pagliari, 'Who Governs Finance? The Shifting Public-Private Divide in the Regulation of Derivatives, Rating Agencies and Hedge Funds' (2011) 18 European Law Journal 44.

${ }^{5}$ [http://www.cftc.gov/index.htm].

6 [http://www.sec.gov/].

${ }^{7}$ [http://ec.europa.eu/internal_market/financial-markets/derivatives/].
} 
from major jurisdictions are also attempting to coordinate cross-border implementation of reforms, for example through the OTC Derivatives Supervisors Group (ODSG) ${ }^{9}$, OTC Derivatives Regulators Forum (ODRF) ${ }^{10}$ and the International Organization of Securities Commissions (IOSCO). ${ }^{11}$ This coordination is partly driven by concerns regarding the potential for fragmentation and arbitrage to emerging derivative markets ('EDMs') and 'offshore' jurisdictions. ${ }^{12}$

In this context, regulatory relationships in financial markets exemplify the importance and changing nature of transnational business governance interactions (TBGI) which, centrally, extend beyond state regulation of market actors, to interaction with transnational private regulatory ${ }^{13}$ arrangements established and operated by industry actors. This interaction involves, but is not limited to, governmental scrutiny of private governance arrangements. Indeed, in some regimes governments are themselves subjects rather than overseers of private governance. In this paper we examine one key case of private governance in financial markets: the emergence, structures and decision-making of Credit Derivatives Determinations Committees (DCs) of the International Swaps and Derivatives Association (ISDA).

The DCs are of particular significance because their role extends beyond the more common standard-setting functions exhibited by many private bodies within transnational regulatory regimes, to embrace key aspects of interpretation and implementation. The DCs determine when 'credit events' under CDS contracts have occurred, triggering a stream of payments, payable only if such events occur. These decisions can profoundly affect the financial positions both of larger corporate actors and of states, as well as the banks which fund them. Therefore, the emergence and implications of the DCs will be the key focus of this chapter, although the broader context within which the DCs were established and operate will also be reviewed, as it offers panoply of instructive examples of TBGI within a single regulatory regime.

\section{ISDA, Pathways of Interaction and the Impact of the GFC}

The governance of OTC derivatives transactions has grown to be a key example of transnational business governance interactions (TBGI) in which the requirements of market actors for a degree of coordination so as to reduce transaction costs has been met by a form of private standard-setting; with a wider structure of activity associated with the implementation of the standards, and with some dynamic engagement of public authorities in oversight and steering. ${ }^{14}$ Therefore, this paper

\footnotetext{
${ }^{8}$ The ESAs comprise the European Banking Authority (EBA) [http://eba.europa.eu/Home.aspx]; European Insurance and Occupational Pensions Authority (EIOPA) [https://eiopa.europa.eu/]; and European Securities and Markets Authority (ESMA) [http://www.esma.europa.eu/].

${ }^{9}$ [http://www.newyorkfed.org/markets/otc derivatives supervisors group.html].

${ }_{10}^{10}$ [http://www.otcdrf.org/].

${ }^{11}$ [http://www.iosco.org/].

${ }^{12}$ See, e.g., C.A. Johnson, Regulatory Arbitrage, Extraterritorial Jurisdiction and Dodd-Frank: The Implications of Global US OTC Derivatives Regulation (University of Utah College of Law Working Paper No 16, 30 October 2012): available at http://papers.ssrn.com/sol3/papers.cfm?abstract id=2169401; T. Rixen, 'Why Reregulation After the Crisis is Feeble: Shadow Banking, Offshore Financial Centres, and Jurisdictional Competition', Regulation \& Governance (forthcoming).

${ }^{13}$ On transnational private regulation (TPR) generally see, C. Scott, F. Cafaggi and L. Senden, 'The Conceptual and Constitutional Challenge of Transnational Private Regulation' (2011) 38 Journal of Law and Society 1.

${ }^{14}$ B. Eberlien et al., 'Interactions in Transnational Business Governance Interactions: Conceptualizing a Terrain' (2013) Regulation \& Governance (forthcoming).
} 
will highlight the following mechanisms or 'pathways' of interaction between the relevant actors, encompassing ISDA, governments, courts and public regulators:

- ISDA's standard-setting through the Master Agreement and associated documentation;

- ISDA's lobbying and other activities in support of the Master Agreement and attempts to shape the broader regulatory regime for OTC derivatives;

- ISDA's intervention as amicus curiae in court cases involving the Master Agreement and that raise important policy issues for ISDA;

- ISDA's advisory role, including to sovereigns, on systemically important events in the OTC derivatives markets; and

- Of key interest in this paper, ISDA's central role in reforming settlement mechanisms in the CDS market following the GFC, notably with the encouragement of public actors; resulting in ISDA itself maintaining a key regulatory role in this space.

Before moving to consider these pathways of interaction, we outline the direction of growth and significance of the markets in derivatives transactions for context. We will then consider in greater detail the governance opportunity which led to the emergence of the peak private governance organisation: ISDA.

\section{a) Growth and Changing Purposes of Derivative Transactions}

Derivative instruments have been defined as agreements between two counterparties where:

'the payoffs to and from each counterparty depend on the outcome of one or more extrinsic, future, uncertain events or metrics - that is, they are "aleatory contracts" - and in which one counterparty expects such outcome to be opposite to that expected by the other counterparty'. ${ }^{15}$

Derivatives proliferate in form but share at least one commonality in that they embody a value which is intrinsically linked or contingent upon some external item of worth; hence they 'derive' their value from something else, referred to as the 'underlying'. ${ }^{16}$ Depending on the type of derivative, the underlying can be a broad range of instruments. These include stocks, bonds, currencies, interest rates, energy, commodities, the weather, ${ }^{17}$ and mortality rates, ${ }^{18}$ for example.

Of particular interest for the purposes of this chapter are derivatives which are contingent on third party or instrument credit quality, ${ }^{19}$ specifically credit default swaps (CDS). Put simply, in a CDS a 'protection buyer' makes periodic payments ('premium') to a 'protection seller' who undertakes to compensate the protection buyer in the event of a relevant 'credit event' (e.g. bankruptcy, restructuring) occurring in relation to the underlying reference entity. A reference entity can be a

\footnotetext{
${ }^{15}$ T.E. Lynch, 'Derivatives: A Twenty First Century Understanding' (2011) 43 Loyola University Chicago Law Journal 1, at 14.

${ }^{16}$ See generally N.M. Feder, 'Deconstructing Over-the-Counter Derivatives' (2002) 3 Columbia Business Law Review 677.

${ }^{17}$ See, e.g., S. Randalls, 'Weather Profits: Weather Derivatives and the Commercialisation of Meteorology' (2010) 40 Social Studies of Science 705.

${ }^{18}$ See, e.g., J.K. Hance, 'Derivatives at Bankruptcy: Lifesaving Knowledge for the Small Firm' (2008) 65 Washington \& Lee Law Review 711, at 726.

${ }^{19}$ See, e.g., F. Partnoy and D.A. Skeel Jnr., 'The Promise and Perils of Credit Derivatives' (2007) 75 University of Cincinnati Law Review 1019.
} 


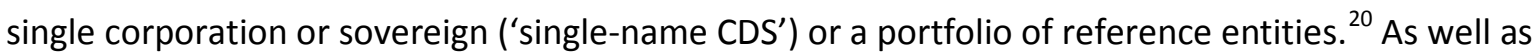
offering the possibility to hedge credit exposure to an underlying reference entity, CDS positions can also effectively act as proxies for adopting speculative positions on relative price movements in underlying reference bonds. ${ }^{21}$

CDSs are of relatively recent vintage. But other derivatives have been deployed throughout history ${ }^{22}$ and from at least the $15^{\text {th }}$ century certain of them have been traded on organised 'exchanges'. ${ }^{23}$ Derivatives exchanges are central venues which facilitate transactions in relatively standardised instruments, such as options and futures. Major derivatives exchanges have historically been selfregulatory organisations (SROs) and have also become subject to a degree of direct public regulatory oversight over time. ${ }^{24}$ Notably, exchange-traded derivatives markets have developed a robust market infrastructure, exemplified by the utilisation of central clearinghouses ('CCPs') to intermediate transactions and dampen risks ${ }^{25}$ (to which we will return later in this chapter).

Throughout history privately negotiated tailored ('bespoke') derivatives have also been traded in the shadow of organised exchanges on an 'over-the-counter' (OTC) basis. Initially, the common law and statutory provisions in major trading jurisdictions were inhospitable to these instruments, largely due to their perceived propensity to inflate speculative bubbles and facilitate significant losses with potentially wider implications. ${ }^{26}$ Moralistic concerns also stoked suspicion of these instruments in earlier periods. ${ }^{27}$ Once public policy towards OTC derivatives, particularly the burgeoning swaps market, ${ }^{28}$ softened in the late twentieth century, they were initially invoked occasionally to fulfil niche hedging strategies. However, this altered significantly throughout the 1990s and 2000s when OTC instruments, including CDSs, became widely traded ${ }^{29}$ or 'commodified' in their own right, in pursuit of purely speculative ${ }^{30}$ activities and regulatory arbitrage. ${ }^{31}$ In turn, this was a driver of the GFC.

\footnotetext{
${ }^{20}$ See, generally, H.B. Shadab, 'Guilty By Association? Regulating Credit Default Swaps' (2010) 4 Entrepreneurial Business Law Journal 407.

${ }^{21}$ See, generally, IOSCO, Report on the Credit Default Swap Market (June 2012): available at http://www.iosco.org/library/pubdocs/pdf/IOSCOPD385.pdf

${ }^{22}$ See, e.g., E.J. Swan, Building the Global Market: A 4000 Year History of Derivatives (London: Kluwer, 2000).

${ }^{23}$ See, e.g., M. D. West, 'Private Ordering at the World's First Futures Exchange' (2000) 98 Michigan Law Review 2574.

${ }^{24}$ See, e.g., G. Poitras, 'From Antwerp to Chicago: The History of Exchange-Traded Derivative Security Contracts' (2009) 20 Revue d'Histoire de Sciences Humaines (2009) 11; S.C. Pirrong, 'The Self-Regulation of Commodity Exchanges: The Case of Market Manipulation' (1995) 38 Journal of Law and Economics 141.

${ }^{25}$ See, e.g., F.R. Edwards, 'The Clearing Association in Futures Markets: Guarantor and Regulator', 3 Journal of Futures Markets (1983) p. 369.

${ }^{26}$ B. Sapien, 'Financial Weapons of Mass Destruction: From Bucket Shops to Credit Default Swaps' (2010) 19 Southern California Interdisciplinary Law Journal 411; L.A. Stout, 'Why the Law Hates Speculators: Regulation and Private Ordering in the Market for OTC Derivatives' (1999) 48 Duke Law Journal 701.

27 J. P. Raines and C.G. Leathers, 'Financial Derivative Instruments and Social Ethics' (1994) 13 Journal of Business Ethics 197; S. Borna and J. Lowry, 'Gambling and Speculation' (1987) 6 Journal of Business Ethics 219.

${ }^{28}$ See, e.g., R. Hodgson, 'The Birth of the Swap' (2009) 65 Financial Analysts Journal 1.

${ }^{29}$ See, e.g., D. Bryan and M. Rafferty, 'Financial Derivatives: The New Gold?' (2006) 10 Competition and Change 265.

${ }^{30}$ On pure speculation in OTC derivatives markets see, e.g., T.E. Lynch, 'Gambling by Another Name; The Challenge of Purely Speculative Derivatives' (2011) 17 Stanford Journal of Law, Business and Finance 67; Stout above n. 26.
} 
Today, the OTC derivative markets are populated by sophisticated participants. These include the largest global dealer banks ('G16') on the 'sell side', ${ }^{32}$ as well as institutional investors, financial institutions, governmental entities and, to some extent, small and medium enterprises (SMEs) and high net worth individuals on the 'buy side'. Specifically in relation to the CDS market, it has been estimated by IOSCO that, as of June 2012:

'[R]oughly $60 \%$ of the outstanding contracts (in terms of gross notional) are concluded between dealers...while the remaining share is represented by contracts between a dealer and a non-dealermostly financial - institutions'. ${ }^{33}$

Intermediaries, such as inter-dealer brokers, and professional services firms, including the major law and accountancy houses, also play important supporting roles in the OTC derivative markets in general.

According to the Bank for International Settlements (BIS) the OTC (including CDS) market is considerably larger than the exchange-traded (ET) segment in notional terms ${ }^{34}$, though it must also be emphasised that headline notional measurements do not reflect mark-to-market and 'netting'related adjustments, coupled with collateralisation; which together generate a smaller 'net notional' figure. ${ }^{35}$ Nonetheless, the OTC derivative markets, and the key players within them, are systemically significant ${ }^{36}$ and immediately prior to the GFC they were susceptible to less direct public regulatory oversight than the ET segment. ${ }^{37}$ In particular, the OTC derivatives markets generally lacked the welldeveloped market infrastructure, such as central clearing, ${ }^{38}$ which characterised the ET segment. Instead, from the 1980s until the GFC OTC derivative market participants primarily relied upon a dominant transnational private regulator across key jurisdictions under the auspices of ISDA ${ }^{39}$; albeit a private regulatory regime that has historically been, and is perhaps even more so now, clearly dependent upon the 'enrolment' ${ }^{40}$ of public capacities.

\footnotetext{
${ }^{31}$ See, e.g., G. Tett, Fools Gold: How Unrestrained Greed Corrupted a Dream, Shattered Global Markets and Unleashed a Catastrophe (London: Little, Brown 2009); F. Partnoy, 'Financial Derivatives and the Costs of Regulatory Arbitrage' (1997) 22 Journal of Corporation Law 211. On regulatory arbitrage generally see V. Fleischer, 'Regulatory Arbitrage' (2011) 89 Texas Law Review 227.

32 See, e.g., M. Cameron, 'G14 Dealer Group Adds Two New Members', Risk.net (1 December 2011): available at http://www.risk.net/risk-magazine/news/2127940/g14-dealer-adds .

${ }^{33}$ IOSCO above n. 21, p. 6.

${ }^{34}$ Compare BIS, OTC Derivatives Market Activity in the First Half of 2012 (13 November 2012): available at http://www.bis.org/publ/otc hy1211.htm with BIS, Exchange-Traded Derivatives Statistics (18 March 2013): available at http://www.bis.org/statistics/extderiv.htm

${ }^{35}$ See Johnson above n. 12.

${ }^{36}$ See, e.g., A. Blundell-Wignall and P.E. Atkinson, 'Global SIFIs, Derivatives and Financial Stability' (2011) OECD Journal, Financial Market Trends (Issue 1). On systemic risk more generally see, e.g., S.L. Schwarcz, 'Systemic Risk' (2008) 97 Georgetown Law Journal 194.

${ }^{37}$ See, e.g., L.A. Stout, 'The Legal Origin of the 2008 Credit Crisis' (2011) 1 Harvard Business Law Review 301.

${ }^{38}$ See, e.g., C. Pirrong, 'The Clearinghouse Cure' (2009) Regulation 44, at 45-46.

${ }^{39}$ For further discussion of ISDA see, e.g., H. McKeen-Edwards and T. Porter, Transnational Financial Associations: Assembling Wealth and Power (New York: Routledge 2013).

${ }^{40}$ See J. Black, 'Enrolling Actors in Regulatory Processes: Examples from UK Financial Services Regulation' (2003) Public Law 62.
} 
The regulatory regime within which ISDA operates epitomises the myriad of explicit and implicit ways in which TBGI manifests itself in the financial markets. Strictly speaking, ISDA itself (as the dominant private regulator) on the one hand, and the broader regulatory regime for OTC derivatives on the other, are not one and the same thing. While ISDA is a very significant (if not the most significant) actor, the broader regime for OTC derivatives also encompasses many other actors who are not ISDA members, such as governments (but who nonetheless have a stake in what ISDA does). Interestingly, the role of public actors has been crucial both to underpinning ISDA's central regulatory role, as well as influencing ISDA's responsibilities and scope of activity in the wake of significant market events, such as the GFC. The next sections will seek to elaborate this point in greater detail before moving to consider perhaps one of the most blatant examples of TBGI in this area, namely the establishment and functions of the DCs.

\section{Drivers of ISDA's Establishment}

ISDA is the principal transnational private trade association and standard-setter for the OTC derivatives markets. It was officially founded in the mid-1980s (initially named the International Swaps Dealers Association), at a time when new OTC derivative products and pricing models were emerging. ${ }^{41}$ The immediate trigger for ISDA's formation was apparently an enquiry from the Financial Accounting Standards Board (FASB) regarding the treatment of swap instruments as 'offbalance sheet' items by major dealer banks. ${ }^{42}$ As such, ISDA was established by, and for, the main OTC dealer banks but its membership constituency (now over 800 ) has since expanded to encompass a broad range of other market participants. ${ }^{43}$ Nevertheless, the 'primary member' dealer banks have arguably continued to wield the majority of influence within ISDA since its foundation. ${ }^{44}$

Aside from concerns regarding the accounting treatment of OTC instruments, one of ISDA's other major early objectives was to defend copyright to an industry-developed standard ('boilerplate') ${ }^{45}$ contract for OTC derivatives transactions, now known as the ISDA Master Agreement (hereinafter 'the Master Agreement'), and related documentation; such as product definitions. The Master Agreement was the progeny of a period of bargaining between the major OTC derivative dealer banks and was an attempt to boost legal certainty and minimise transaction costs in the relatively nascent, but potentially lucrative, OTC financial derivatives markets. ${ }^{46}$ As a result, the ISDA Master

\footnotetext{
${ }^{41}$ R.C. Merton, 'Theory of Rational Option Pricing' (1973) 4 Bell Journal of Economics and Management Science 141; F. Black and M. Scholes, 'The Pricing of Options and Corporate Liabilities (1973) 81 Journal of Political Economy 637.

${ }^{42}$ F. Partnoy, Infectious Greed: How Deceit and Risk Corrupted the Financial Markets (Philadelphia: PublicAffairs 2009), pp. 43-44.

43 ISDA, ISDA Members List: available at https://www2.isda.org/membership/members-list/.

${ }^{44}$ See, e.g., R.E. Litan, The Derivatives Dealer's Club and Derivatives Markets Reform: A Guide for Policy

Makers, Citizens and Other Interested Parties (Brookings Institute, April 2010): available at http://www.brookings.edu/ /media/research/files/papers/2010/4/07\%20derivatives\%20litan/0407 derivativ es litan.pdf

45 On boilerplate see, e.g., K.E. Davis, 'The Role of Nonprofits in the Production of Boilerplate' (2006) 104

Michigan Law Review 1075; M. Kahan and M. Klausner, 'Standardization and Innovation in Corporate Contracting (or "The Economics of Boilerplate")', 83 Virginia Law Review (1997) 713.

${ }^{46}$ See, e.g., S.M. Flanagan, 'The Rise of a Trade Association: Group Interactions within the International Swaps and Derivatives Association' (2001) 6 Harvard Negotiation Law Review 211; J.B. Golden, 'Setting Standards in the Evolution of Swap Documentation' (1994) 13 International Financial Law Review 18.
} 
Agreement and related documentation are now the dominant standards for OTC derivatives transactions across major trading jurisdictions. ${ }^{47}$ ISDA's initial mission also encapsulated lobbying activities extending beyond, though ultimately related to, ISDA's role as vanguard of the Master Agreement.

Faced with a certain degree of public regulatory ambiguity towards new OTC products in the late 1980s and 1990s in the large US and UK markets, ${ }^{48}$ and against a politico-economic backdrop espousing the efficient markets hypothesis, ${ }^{49}$ ISDA's lobbying was salient. Given that ISDA's membership encompasses some of the largest financial institutions on the globe, its influence and apparent expertise were duly recognised by public policy makers. Overall, ISDA can be considered to have been pivotal in shepherding a public deregulatory trend; climaxing in the late 1990s/early 2000s with the enactment of 'OTC derivatives-friendly' legislation, such as the Commodity Futures Modernization Act (CFMA) in the US for instance. ${ }^{50}$ ISDA's influence in this respect has been starkly summarised by Frank Partnoy as follows:

'Anyone who imagined that members of Congress, or their staffs, drafted laws regarding derivatives would have been surprised to peek inside the offices of the House Agriculture Committee during the time Congress was considering the CFMA. Instead of seeing members of Congress at work, you would have seen Mark Brickell, the lobbyist from ISDA, writing important pieces of the legislation'. ${ }^{51}$

ISDA's mantra, as well as that of its allies in this period, was that OTC derivative markets were niche and technical but nonetheless capable of fulfilling generally beneficial economic functions. It was posited that a significant degree of direct public regulatory oversight was unwarranted and that 'sophisticated' industry participants were capable of safely self-regulating. The existence of an established boilerplate contract, such as the Master Agreement, and related documentation was undoubtedly a powerful 'signal' ${ }^{52}$ to public actors in this regard. But it must also be stressed that ISDA's stance was deemed credible at the time and attracted considerable support, not least from high profile public policy makers. ${ }^{53}$

More broadly, ISDA and/or some of its major members have successfully encouraged national governments to enact so-called settlement 'safe harbours', incorporating exemptions from bankruptcy and gaming laws, for OTC derivatives ${ }^{54}$; with a view to ensuring that 'close-out netting' ${ }^{55}$

\footnotetext{
${ }^{47}$ For instance, as of May 201285 per cent of credit support documentation in OTC trades used the ISDA standard. See ISDA, Margin Survey 2012 (May 2012): available at http://www2.isda.org/functionalareas/research/surveys/margin-surveys/.

${ }^{48}$ See, e.g., D. Awrey, 'The FSA, Integrated Regulation and the Curious Case of OTC Derivatives' (2010) 13 University of Pennsylvania Journal of Business Law 1.

${ }^{49}$ On efficient capital markets theory see, e.g., E.F. Fama, 'Efficient Capital Markets: A Review of Theory and Empirical Work' (1970) Journal of Finance 383.

${ }^{50}$ See Stout above n. 37; M. Greenberger, 'Overwhelming a Financial Regulatory Black Hole with Legislative Sunlight: Dodd-Frank's Attack on Systemic Economic Destablization Caused by an Unregulated Multi-Trillion Dollar Derivatives Market' (2011) 6 Journal of Business and Technology Law 127.

${ }^{51}$ Partnoy, above n.42, p. 293.

52 On a similar theme in the context of collective action clauses (CACs) see, A. Gelpern and M. Gulati, 'Public Symbol in Private Contract: A Case Study' (2006) 84 Washington University Law Review 1627.

${ }^{53}$ See, e.g., US Department of the Treasury, Treasury Deputy Secretary Lawrence T. Summers Testimony Before the US Senate Committee on Agriculture, Nutrition and Forestry on the CFTC Concept Release (30 July 1998), available at: http://www.treasury.gov/press-center/press-releases/Pages/rr2616.aspx.

${ }^{54}$ And which can also encompass other instruments, such as repurchase agreements ('repos').
} 
is legally permissible. ISDA's (contestable) ${ }^{56}$ posture is that these safe harbours are crucial for guaranteeing legal certainty and thereby underpinning financial stability. Additionally, enactment of such legislation is often explicitly or implicitly positioned as being central to ensuring an attractive environment for financial services businesses and, in particular, in supporting the growth of OTC derivatives markets. ${ }^{57}$

It is notable that ISDA offers a 'model netting law' ${ }^{58}$ as a template for enactment of such legislation and there are clear examples of national legislators having followed the substance, if not the form, of this instrument. ${ }^{59}$ Although ostensibly a 'technical' matter, these interactions thus carry strong normative undertones. ${ }^{60}$ Hence, ISDA's relationship with sovereigns in this respect may constitute what Fabrizio Cafaggi has branded 'ex-post recognised private regulation'. ${ }^{61}$ Furthermore, through its safe harbour legislation project it could be suggested that ISDA has engaged in a certain degree of 'private oversight of the public sector'. ${ }^{62}$

Related to these activities, ISDA commissions legal opinions for members on the enforceability of its Master Agreement and associated collateral (security) arrangements across jurisdictions. ${ }^{63}$ In fact, the deployment of collateral, which aims to secure contracts and mitigate fallout in the event of default, has played (and will likely continue to play) a highly significant regulatory role in the OTC

${ }^{55}$ Defined as 'a process involving termination of obligations under a contract with a defaulting party and subsequent combining of positive and negative replacement values into a single net payable or receivable' in D. Mengle, Close Out Netting and Risk Management in Over-the-Counter-Derivatives (Working Paper, June 2010): available at http://papers.ssrn.com/sol3/papers.cfm?abstract id=1619480; See also P. Werner, The Importance of Close Out Netting (ISDA: Research Notes No.1/2010, 2010): available at http://www2.isda.org/search?keyword=netting.

${ }^{56}$ See, e.g., A. Blundell-Wignall and P.E. Atkinson, 'Deleveraging, Traditional Versus Capital Markets Banking and the Urgent Need to Separate GSIFI Banks' (2012) OECD Journal, Financial Market Trends (issue 1), at 33; D. Duffie and D.A. Skeel Jnr., A Dialogue on the Costs and Benefits of Automatic Stays for Derivatives and Repurchase Agreements (University of Pennsylvania Institute for Law \& Economics Research Paper No. 12-02, March 2012): available at http://papers.ssrn.com/sol3/papers.cfm?abstract id=1982095; M.J. Roe, 'The Derivatives Market's Payment Priorities as Financial Crisis Accelerator' (2011) 63 Stanford Law Review 539; S.J. Lubben, 'Repeal the Safe Harbours' (2010) 18 American Bankruptcy Institute Law Review 319; Robert R. Bliss \& George G. Kaufman, 'Derivatives and Systematic Risk: Netting, Collateral and Closeout', (2006) 2 Journal of Financial Stability 55.

${ }^{57}$ See, e.g., ISDA, ISDA Submission to Indian Authorities on Consistency of Netting Application to Spur Economic Growth (12 October 2012): available at http://www2.isda.org/search?headerSearch=1\&keyword=netting.

${ }^{58}$ ISDA, Model Netting Act: available at http://www.isda.org/docproj/model_netting.html

${ }^{59}$ See, e.g., A. Riles, The Transnational Appeal of Formalism: The Case of Japan's Netting Law (Stanford/Yale Junior Faculty Forum Research Paper 00-03, 2000) pp. 29-30: available at

http://ssrn.com/paper.taf?abstract id=162588 (Japan); J. Biggins and C. Scott, 'Public-Private Relations in a Transnational Private Regulatory Regime: ISDA, the State and OTC Derivatives Market Reform' (2012) 13 European Business Organization Law Review 307, at 329-332 (Ireland).

${ }^{60}$ See, e.g., Biggins and Scott above n. 59; G. Morgan, 'Market Formation and Governance in International Financial Markets: The Case of OTC Derivatives' (2008) 61 Human Relations 637. More generally, it has been questioned whether even the most technical areas of private governance can ever be free of political contestation affecting interests: T. Büthe, and W. Mattli, The New Global Rulers: The Privatization of Regulation in the World Economy (Princeton, NJ: Princeton University Press, 2011).

${ }^{61}$ F. Cafaggi, Rethinking Private Regulation in the European Regulatory Space (European University Institute, Working Paper LAW No. 2006/13) pp. 23-24 (paper on file with authors).

62 C. Scott, 'Private Regulation of the Public Sector: A Neglected Facet of Contemporary Governance' (2002) 29 Journal of Law and Society 56-76.

${ }^{63}$ ISDA, Opinions: available at http://www2.isda.org/functional-areas/legal-and-documentation/opinions/ 
derivatives markets. ${ }^{64}$ The use of collateral in OTC transactions has been described by Annelise Riles as a 'kind of private constitution for the parties' ongoing relationship' ${ }^{65}$ Other mechanisms invoked to underpin the integrity of the ISDA's private regulatory role include, for instance, choice of law clauses and accompanying guidance within the Master Agreement and related documentation. These have the clear aim of confining litigation to jurisdictions which are less likely to deliver major interpretative shocks to ISDA's interests. ${ }^{66}$ ISDA has also increasingly intervened as amicus in court cases which are deemed to raise important policy issues for the OTC derivative markets. This role has intensified on foot of increased rates of litigation involving the Master Agreement following the GFC. ${ }^{67}$

Notably, while alternative dispute resolution was not a pervasive mechanism in the OTC derivative markets prior to the GFC, it is now reportedly gaining popularity amongst market participants. ${ }^{68}$ In this sphere, ISDA has assumed a key role within a recent high-profile initiative, known as the Panel of Recognised International Market Experts in Finance (P.R.I.M.E. Finance). ${ }^{69}$ Additionally, ISDA arguably exerts subtler forms of influence by actively engaging in legal harmonisation initiatives encompassing public and private actors, for instance under the auspices of the International Institute for the Unification of Private Law (UNIDROIT). ${ }^{70}$

Aside from this, ISDA has occasionally engaged in other types of activities which have similarly influenced the terms of reference within which its standards and norms operate and, in so doing, inevitably brought it into close contact with public actors. These activities have also served to illustrate the sheer extent of ISDA's power in the financial markets. For example, Anna Gelpern has highlighted an intriguing incident in 1998 whereby the Japanese Government approached ISDA for advice in relation to the distressed Long-Term Credit Bank ('LTCB'). ${ }^{71}$ Following this approach and discussions with the Japanese authorities, ISDA agreed to issue a statement with a view to providing clarity and calming the markets in the context of LTCB's nationalisation. ISDA's statement has been branded by Gelpern as a 'private "no action letter" of sorts - that pre-empted a rush for the exits'. ${ }^{72}$ If such a statement were to be issued by a national government, it could be considered an instrument of soft law.

\footnotetext{
${ }^{64}$ See, e.g., ISDA, ISDA Margin Survey 2012 (1 May 2012): available at http://www2.isda.org/functionalareas/research/surveys/margin-surveys/.

${ }^{65}$ A. Riles, 'The Anti-Network: Private Global Governance, Legal Knowledge, and the Legitimacy of the State' (2008) 56 American Journal of Comparative Law 605, at 612.

${ }^{66}$ See, e.g., J. Biggins, "'Targeted Touchdown" and "Partial Liftoff": Post Crisis Dispute Resolution in the OTC Derivatives Markets and the Challenge for ISDA' (2012) 13 German Law Journal 1297. See also, e.g., J.P. Braithwaite, 'Standard Form Contracts as Transnational Law: Evidence from the Derivatives Markets' (2012) 75 Modern Law Review 779; J. Black and D. Rouch, 'The Development of the Global Markets as Rule-Makers: Engagement and Legitimacy' (2008) 2 Law and Financial Markets Review 218.

${ }^{67}$ ISDA, Amicus Briefs: available at http://www2.isda.org/functional-areas/legal-and-documentation/amicusbriefs/; J.P. Braithwaite, 'OTC Derivatives, the Courts and Regulatory Reform' (2012) 7 Capital Markets Law Journal 364, at 367-368.

${ }^{68}$ See, e.g., ISDA, ISDA Publishes the 2013 Arbitration Guide [http://www2.isda.org/news/isda-publishes-the2013-isda-arbitration-guide].

${ }^{69}$ [http://www.primefinancedisputes.org/]. For discussion see J. Golden, 'Judges and Systemic Risk in the Financial Markets' (2013) 18 Fordham Journal of Corporate and Financial Law 327.

${ }^{70}$ UNIDROIT, Principles and Rules on the Netting of Financial Instruments: available at http://www.unidroit.org/english/studies/study78c/main.htm

${ }^{71}$ A. Gelpern, 'Commentary: Public Promises and Organizational Agendas' (2009) 51 Arizona Law Review 57

72 Ibid., at 61.
} 
At this juncture and in view of the preceding analysis, it is worth reflecting on the factors that may have been important in cementing ISDA's role as the dominant private regulator within the broader regulatory regime for OTC derivatives. In analysing this, it is instructive to consider ISDA's role in comparative perspective, specifically with reference to Tim Büthe's extrapolation of the reasons for the emergence and solidification of another technical regulator, the International Electrotechnical Commission (IEC); a key standard-setter for electrical, electronic and related technologies. ${ }^{73}$ It is clear that the emergence and embedment of ISDA and the IEC share many parallels. Both were founded early in the development of their respective industries, which was important to both in establishing themselves as 'focal' regulators. ${ }^{74}$

Furthermore, both ISDA and the IEC underpinned their dominant positions by emphasising their technical expertise. As highlighted by Büthe, in reference to the work of Thomas Risse, such technical expertise can fulfil important functions for regulators, promoting their legitimacy in the eyes of other stakeholders. In particular, such technical expertise can 'at least allow for persuasion....and appear a-political.$^{75}$ Aside from the IEC, this logic can also be neatly applied to certain of ISDA's activities. For instance, ISDA has deployed its expertise to develop a highly regarded standard-form contract (the Master Agreement). This stock of perceived technical expertise has, in turn, also lent weight to ISDA's (ostensibly a-political) position on the importance of ensuring legal enforceability for close-out netting ('safe harbours') across jurisdictions. ISDA has justified this on technical (legal and risk-based) grounds, notwithstanding the distributional (third party) effects such safe harbours may potentially imply. ${ }^{76}$

Over time, ISDA's perceived technical expertise in these areas has rendered it a natural advisor on broader systemically important developments in the OTC derivatives markets, including those which have attracted the attention of sovereigns; as exemplified in the Japanese LTCB incident and as will be highlighted further below in relation to the post-GFC deliberations of public regulators in major OTC derivative jurisdictions. Similar to the IEC, it is difficult to argue that ISDA has not actively sought pre-eminence. In fact, there is ample evidence that ISDA has explicitly done so, especially given that ISDA's lobbying positions frequently equate optimal outcomes in the OTC derivatives markets with adherence to ISDA's own standards and norms. ${ }^{77}$

Therefore, the range of ISDA's activities has, as Tony Porter has suggested elsewhere, rendered it very difficult for another private challenger to compete with it. ${ }^{78}$ Where such challenges have materialised in the past, ISDA has actively grappled with them. ${ }^{79} \mathrm{It}$ is, for the reasons outlined above,

\footnotetext{
${ }^{73}$ T. Büthe, 'Engineering Uncontestedness? The Origins and Institutional Development of the International Electrotechnical Commission (IEC)' (2010) 12 Business and Politics (Article 4).

${ }^{74}$ Ibid., at 11.

${ }^{75}$ Ibid.

${ }^{76}$ See above n. 56.

${ }^{77}$ See, e.g., ISDA, ISDA Comments on the Introduction of Netting Provisions into Russian Legislation (6 April 2011): available at http://www2.isda.org/search?headerSearch=1\&keyword=russia

${ }^{78}$ T. Porter, 'Technical Systems and the Architecture of Transnational Business Governance' (2013) Regulation \& Governance (forthcoming).

${ }^{79}$ ISDA, Letter to European Banking Federation on a European Master Agreement for Financial Transactions (19th June 1998) [http://www.isda.org/speeches/pdf/European-Master-Agreement-for-Financial-Tansactions19Jun99.pdf].
} 
perhaps not surprising that such competitors have, to date, not managed to seriously threaten ISDA's space. Evidently and importantly, states have also played a role in incubating ISDA's dominant regulatory role in the sense that states have, at the very least, traditionally been 'facilitative' ${ }^{80}$ of ISDA. Overall therefore, it is clear that the private element (articulated through ISDA) of the broader regulatory regime for OTC derivatives is not 'anational'. Instead, ISDA could be described as 'beyond, but not without, the nation state' ${ }^{81}$ Ultimately, ISDA does not set industry standards and norms which operate in a vacuum. Rather, ISDA appears to be engaging in what David Snyder might characterise as a form of 'private lawmaking' which has the capacity to clearly affect both members and non-members and thus can be considered to have 'the effect of law' ${ }^{82}$ And, as Ralf Michaels has observed, nation states may attempt to 'domesticate this potentially subversive development through the incorporation of the norms that are created'. ${ }^{83}$

In principle, the fallout from the GFC theoretically had the potential to challenge this dynamic, especially ISDA's focal role. But, as will be illustrated, what actually occurred following the GFC was perhaps closer to 'institutional layering' in many respects. ${ }^{84}$ In other words, due to its dominance and perhaps the perceived costs associated with creating an entirely new regulatory regime, ISDA was actually endowed with new responsibilities by public actors, exemplified by the establishment of the DCs. This effectively added adjudication and interpretative responsibilities with respect to a systemically important segment of the OTC derivatives markets to ISDA's existing regulatory repertoire, which already included standard-setting, norm promotion and advisory functions. Before moving to consider this in more detail, it is first necessary to review the GFC for context.

\footnotetext{
${ }^{80}$ On the facilitative role of states see, e.g., R. Wai, 'Transnational Private Law and Private Ordering in a Contested Global Society' (2005) 46 Harvard International Law Journal 471, at 475.

${ }^{81}$ For discussion see, e.g., R. Michaels, 'The True Lex Mercatoria: Law Beyond the State' (2007) 14 Indiana Journal of Global Legal Studies 447

82 D. Snyder, 'Private Lawmaking' (2003) 64 Ohio State Law Journal 371-448.

83 R. Michaels, 'The Re-Statement of Non-State Law: the State, Choice of Law, and the Challenge From Global Legal Pluralism' (2005) 51 The Wayne Law Review 1210-1259.

${ }^{84}$ Büthe, above n.73, at 16.
} 
Figure 1: ISDA and the Nation State

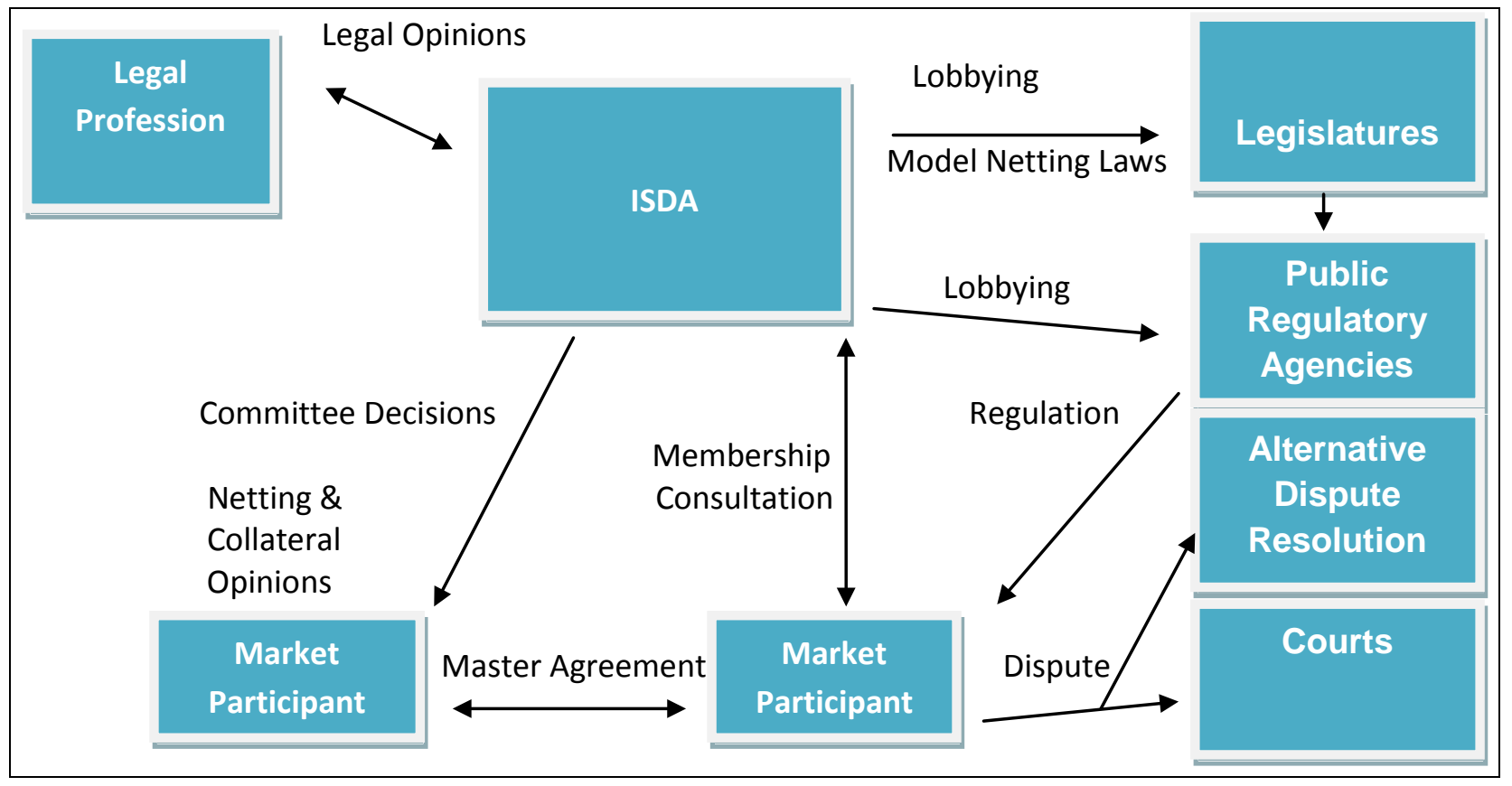

d) Derivatives, ISDA and the GFC

The GFC was not the first market crisis which featured derivatives trading gone awry, ${ }^{85}$ though its severity arguably does distinguish it from previous panics. ${ }^{86}$ It is unlikely that the GFC will be the last market disruption to have a derivatives-related hue either. ${ }^{87}$ But it is also generally accepted that OTC derivatives did not, in and of themselves, prompt the collapse of major institutions and trigger the GFC. ${ }^{88}$ Instead, amongst other matters, the nature and extent of securitisation and related OTC derivatives' deployment ${ }^{89}$; the resulting interconnectedness between systemic market participants ${ }^{90}$; informational asymmetries ${ }^{91}$; the form and implementation of pre-GFC public

\footnotetext{
${ }^{85}$ See, e.g., P.M. Garber, 'Famous First Bubbles' (1990) 4 Journal of Economic Perspectives 35; R. Lowenstein, When Genius Failed: The Rise and Fall of Long-Term Capital Management (New York: Random House, 2000). ${ }^{86}$ See, e.g., G.B. Gorton, Misunderstanding Financial Crises: Why We Don't See Them Coming (Oxford: Oxford University Press, 2012); C.M. Reinhardt and K.S. Rogoff, This Time is Different: Eight Centuries of Financial Folly (New Jersey: Princeton University Press, 2009).

${ }^{87}$ For instance the more recent JPMorgan Chase 'Whale Trades' generated some concern in the derivatives markets. See, e.g., US Senate Committee on Homeland Security and Governmental Affairs Permanent Subcommittee on Investigations, JPMorgan Chase Whale Trades: A Case History of Derivatives Risks and Abuses (15 March 2013): available at http://www.hsgac.senate.gov/subcommittees/investigations/hearings/chase-whale-trades-a-case-history-ofderivatives-risks-and-abuses; H.T.C. Hu, "Too Complex to Depict? Innovation, "Pure Information", and the SEC Disclosure Paradigm' (2012) 90 Texas Law Review 1601.

${ }^{88}$ V. Reinhart, 'A Year of Living Dangerously: The Management of the Financial Crisis in 2008' (2011) 25 Journal of Economic Perspectives 71.

${ }^{89}$ See, e.g., G.B. Gorton, Slapped in the Face by the Invisible Hand: Banking and the Panic of 2007 (Yale University and National Bureau of Economic Research Working Paper, May 2009): available at http://papers.ssrn.com/sol3/papers.cfm?abstract id=1401882

${ }^{90}$ See, e.g., R.M. Lastra, 'Systemic Risk, SIFIs and Financial Stability' (2011) 6 Capital Markets Law Journal 197.

${ }^{91}$ See, e.g., R. Bartlett III, 'Inefficiencies in the Information Thicket: A Case Study of Derivatives Disclosures During the Financial Crisis' (2010) 36 Journal of Corporation Law 1.
} 
regulatory frameworks ${ }^{92}$; and the idiosyncrasies of human ${ }^{93}$ (mostly male) ${ }^{94}$ actors coalesced to stoke the GFC. ISDA forcefully argues that the fallout from certain institutional implosions, such as that of Lehman Brothers, ${ }^{95}$ have ultimately been less traumatic for the OTC derivative markets than might originally have been anticipated. ${ }^{96}$ In Lehman's case, ISDA largely attributes this to Lehman's observance of OTC derivative market risk management practices and the operation of ISDA's own Master Agreement-related close-out processes. ${ }^{97}$

Nevertheless, the distresses of other OTC derivative market players, such as insurance giant American International Group (AIG), were patently different. ISDA, as well as other observers, tend to characterise AIG's predicament as somewhat sui generis. While the proximate reasons for AIG's collapse have been extensively outlined elsewhere, ${ }^{98}$ it is clear that AIG (specifically its Financial Products division) engaged in a considerable degree of speculative activity in the CDS markets ${ }^{99}$ and at the same time did not observe prudent margining (collateral) practices. ${ }^{100}$ This significantly contributed to a pooling of risk within AIG and the creation of systemically important interconnections, which AIG was unable to extricate itself from as the GFC flared up in 2007 and $2008 .^{101}$

\footnotetext{
92 See, e.g., E.K. Gerding, 'Code, Crash and Open Source: The Outsourcing of Financial Regulation to Risk Models and the Global Financial Crisis' (2009) 84 Washington Law Review 127.

93 See, e.g., D.C. Langevoort, 'Chasing the Greased Pig Down Wall Street: A Gatekeeper's Guide to the Psychology, Culture and Ethics of Financial Risk Taking' (2011) 96 Cornell Law Review 1209; S. Rosen, 'The Economics of Superstars' (1981) 71 American Economic Review 845; R.H. Thaler and E.J. Johnson, 'Gambling with the House Money and Trying to Break Even: The Effects of Prior Outcomes on Risky Choice' (1990) 36 Management Science 643.

${ }^{94}$ See, e.g., See, e.g., C.L. Apicella et al., 'Testosterone and Financial Risk Preferences' (2008) 29 Evolution and Human Behaviour 384; J.M. Coates and J. Herbert, 'Endogenous Steroids and Financial Risk Taking on a London Trading Floor' (2008) 105 Proceedings of the National Academy of Sciences of the United States of America 6167; E. Prugl, "'If Lehman Brothers Had Been Lehman Sisters...": Gender and Myth in the Aftermath of the Financial Crisis' (2012) 6 International Political Sociology 21; C.S. Chung, 'From Lily Bart to the Boom Boom Room: How Wall Street's Social and Cultural Response to Women has Shaped Securities Regulation' (2010) 33 Harvard Journal of Law and Gender 176.

${ }^{95}$ For general discussion see, e.g., Satyajit Das, In the Matter of Lehman Brothers, 59 WILMOTT 20 (2012).

${ }^{96}$ Though of course that is not to say that there were no negative effects. See, e.g., N. Dumontaux and A. Pop, 'Understanding the Market Reaction to Shockwaves: Evidence from the Failure of Lehman Brothers' (2013) Journal of Financial Stability (forthcoming).

${ }^{97}$ ISDA, Non-Cleared OTC Derivatives: Their Importance to the Global Economy (March 2013): available at http://www2.isda.org/functional-areas/research/studies/

${ }^{98}$ See, e.g., US Government Accountability Office, Financial Crisis: Review of Federal Reserve System Financial Assistance to American International Group plc. (Report to Congressional Requesters: September 2011): available at http://www.gao.gov/assets/590/585560.pdf; W.K. Sjostrum Jnr., 'The AIG Bailout' (2009) 66 Washington and Lee Law Review 943.

${ }^{99}$ R.M. Stulz, 'Credit Default Swaps and the Credit Crisis' (2010) 24 Journal of Economic Perspectives 73, at 83. ${ }^{100}$ See ISDA above n. 97.

${ }^{101}$ On the GFC generally see, e.g., E. Helleiner, 'Understanding the 2007-2008 Global Financial Crisis: Lessons for Scholars of International Political Economy' (2011) 14 Annual Review of Political Science 67; K.T. Jackson, 'The Scandal Beneath the Financial Crisis: Getting a View from a Moral-Cultural Mental Model' (2010) 33 Harvard Journal of Law \& Public Policy 735; A.E. Wilmarth Jnr., 'The Dark Side of Universal Banking: Financial Conglomerates and the Origins of the Subprime Financial Crisis' (2009) 41 Connecticut Law Review 963; S.T. Omarova, 'The Quiet Metamorphis: How Derivatives Changed the Business of Banking' (2009) 63 University of Miami Law Review 1041; M.K. Brunnermeier, 'Deciphering the Liquidity and Credit Crunch 2007-2008' (2009) 23 Journal of Economic Perspectives 77.
} 
Accordingly, while AIG's specific situation may have technically been sui generis, the fact remains that AIG's foray into the CDS markets and subsequent difficulties generated negative externalities. US authorities were compelled to support AIG with public funding, thereby also ensuring that AIG's outstanding obligations on its OTC derivatives portfolio were honoured. ${ }^{102}$ In sum, the rescue of AIG generated a social cost. Of course, AIG was not the only financial institution to require publiclyfunded assistance in the throes of the GFC but is illustrative for present purposes insofar as its exposure to CDS's was a key factor in its collapse.

In the wake of the GFC and related institutional and market failures, the G20 nations resolved to overhaul infrastructure in the OTC derivatives markets. ${ }^{103}$ This agenda, which is being monitored by the Financial Stability Board (FSB $)^{104}$, demands, inter alia, increased central clearing and/or exchange (or platform) trading of OTC derivatives where appropriate, as well as enhanced risk management practices and public reporting generally. At time of writing, G20 jurisdictions are at various stages of implementation, with the largest $\mathrm{US}^{105}$ and $\mathrm{EU}^{106}$ markets most advanced. Aside from these direct market infrastructure reforms, other elements of public regulatory reform on both sides of the Atlantic are also likely to impinge on the manner and extent to which certain banking entities will be permitted to engage in OTC derivative trading ${ }^{107}$; as per the so-called 'Volcker' and 'Swaps Push-Out' Rules in the US ${ }^{108}$ and, potentially, a bank 'ring-fencing' initiative at EU level. ${ }^{109}$ The EU has also

\footnotetext{
${ }^{102}$ For details see, e.g., US Office of the Special Inspector General of the Troubled Asset Relief Program, Quarterly Report to Congress (30 January 2010), p. 9: available at http://www.sigtarp.gov/Quarterly\%20Reports/January2010 Quarterly Report to Congress.pdf; ISDA,
} Counterparty Credit Risk Management in the US Over-the-Counter Derivatives Markets (August 2011): available at http://www2.isda.org/search?headerSearch=1\&keyword=monoline

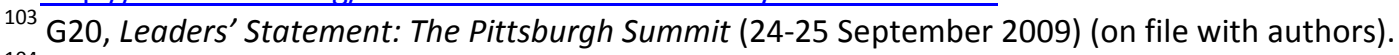

${ }^{104}$ FSB, OTC Derivatives: available at http://www.financialstabilityboard.org/list/fsb publications/tid 149/index.htm .

${ }^{105}$ Under the Dodd-Frank Wall Street Reform and Consumer Protection Act, Pub. L. 111-203, H.R. 4173 (2010) (US). For information on implementing rules see, e.g., CFTC, Dodd-Frank Act: available at http://www.cftc.gov/LawRegulation/DoddFrankAct/index.htm; SEC, SEC Final Rules: available at http://www.sec.gov/rules/final.shtml

${ }^{106}$ Under Regulation (EU) No 648/2012 of the European Parliament and of the Council of 4 July 2012 on OTC derivatives, central counterparties and trade repositories [2012] OJ L 201/1 ('European Market Infrastructure Regulation'); European Commission, Investment Services Directive - Markets in Financial Instruments Directive (MiFID): available at http://ec.europa.eu/internal market/securities/isd/mifid en.htm. For information on implementing regulations see, e.g., European Commission, Derivatives/EMIR: available at http://ec.europa.eu/internal market/financial-markets/derivatives/\#maincontentSec1.

${ }^{107}$ For discussion see, e.g., J.T.S. Chow and J. Surti, Making Banks Safer: Can Volcker and Vickers Do It? (IMF Working Paper 11/236, November 2011): available at http://www.imf.org/external/pubs/ft/wp/2011/wp11236.pdf; A. Blundell Wignall, G. Wehinger and P. Slovik, 'The Elephant in the Room: The Need to Deal with what Banks Do' (2009) OECD Journal, Financial Market Trends (Issue 2).

${ }^{108}$ For discussion of these measures see, e.g., C.K. Whitehead, 'The Volcker Rule and Evolving Financial Markets' (2011) 1 Harvard Business Law Review 39; C.T. Fowler, 'The Swaps Push Out Rule: An Impact Assessment' (2011) 15 North Carolina Banking Institute 205; R.S. Bloink, 'Does the Dodd-Frank Wall Street Reform Act Rein in Credit Default Swaps? An EU Comparative Analysis', 89 (2011) Nebraska Law Review 587. ${ }^{109}$ European Commission, Final Report of the High-Level Expert Group on Reforming the Structure of the EU Banking Sector (2 October 2012): available at http://ec.europa.eu/internal market/bank/docs/highlevel expert group/report en.pdf 
issued a (somewhat controversial) ${ }^{110}$ regulation specifically concerned with short selling and CDS which elaborates certain restrictions and notification requirements for purely speculative ('uncovered') sovereign CDS, subject to exemptions. ${ }^{111}$

This is only a high-level snapshot of the array of public regulatory reforms now underway in the financial sector. However, perhaps tellingly, the market infrastructure reform agenda has not sought to fundamentally challenge certain norms which became embedded in the OTC derivatives markets since the late 1980s, and which are important to ISDA. For example, OTC derivatives trading will continue, in general, ${ }^{112}$ to operate outside the purview of gambling and insurance laws in major jurisdictions, irrespective of the economic purpose of transactions. ${ }^{113}$ Overall therefore, public actors have not 'thrown out the baby with the bathwater', especially given that ISDA has, for instance, been utilised by major public regulatory authorities as a conduit for communicating with major market participants on the implementation of market infrastructure reforms. In turn, ISDA has reorganised its internal structures in order to streamline these interactions and to prepare its members for incoming regulatory reforms, ${ }^{114}$ as well as seeking to afford a stronger voice to 'buy side' members and other relevant stakeholders.

It is thus clear that ISDA, for its part, has at least outwardly embraced the general objectives of public regulatory reform, ${ }^{115}$ though has also not hesitated to robustly challenge aspects of implementation, particularly through its revamped public relations machine. ${ }^{116}$ Moreover, certain reforms in the OTC derivatives markets have arguably seen ISDA actually increase its influence in some respects; exemplified by the establishment of the DCs. This influence and retention of 'regulatory share ${ }^{117}$ has, however, occasionally brought with it certain pressures and expectations from the direction of public actors and other stakeholders.

\footnotetext{
${ }^{110}$ See, e.g., International Monetary Fund, 'Chapter 2: A New Look at the Role of Sovereign Credit Default Swaps', Global Financial Stability Report (April 2013): available at http://www.imf.org/external/pubs/ft/gfsr/2013/01/pdf/c2.pdf

${ }^{111}$ Regulation (EU) No 236/2012 of the European Parliament and of the Council of 14 March 2012 on Short Selling and Certain Aspects of Credit Default Swaps [2012] OJ L 86/1.

${ }^{112}$ Although individual derivative contracts can theoretically fall foul of common law and/or legislative provisions nonetheless. See, e.g, K. Blizzard, The Law of Financial Derivatives in Ireland (Roundhall: Dublin 2012).

${ }^{113}$ See, e.g., Biggins and Scott above n. 59. See also, e.g., L.A. Stout, 'Uncertainty, Dangerous Optimism and Speculation: An Inquiry into Some Limits of Democratic Governance' (2012) 97 Cornell Law Review 1177; T.L Hazen, 'Disparate Regulatory Regimes for Parallel Activities: Securities Regulation, Derivatives Regulation, Gambling and Insurance' (2005) 24 Annual Review of Banking and Financial Law 376.

${ }^{114}$ ISDA, IIGC Committees: available at http://www2.isda.org/committees/iigc-committees/; ISDA, Protocol Management: available at http://www2.isda.org/functional-areas/protocol-management/about-isdaprotocols/

${ }^{115}$ See, e.g., ISDA, ISDA Overview 2013: Global Derivatives - More Challenge Ahead (19 April 2013): available at http://www2.isda.org/

${ }^{116}$ See, e.g., ISDA, Newsroom: available at http://www2.isda.org/newsroom/

${ }^{117}$ See J. Black, Legitimacy and the Competition for Regulatory Share (LSE Legal Studies Working Paper No.

14/2009): available at http://papers.ssrn.com/sol3/papers.cfm?abstract id=1424654
} 


\section{The Emergence and Significance of the ISDA Credit Derivatives Determinations Committees}

As the GFC began to bite in March 2008, the US President's Working Group on Financial Markets ${ }^{118}$ (PWG) issued a policy statement outlining its assessment of the roots of market turmoil and recommendations for addressing it. ${ }^{119}$ The prevailing industry settlement process for credit derivatives was amongst the issues which attracted the attention of the PWG.

\section{a) Settlement Concerns}

The PWG policy statement noted risks relating to settlement backlogs, particularly in credit derivatives, which had occurred prior to the GFC. The potential implications of this cannot be underestimated. For instance, it has been highlighted that for every 100 credit derivative contracts entered into by a major dealer bank in 2005, there were approximately 1,000 'aged unconfirmed' trades outstanding. ${ }^{120}$ Patently, this generated a degree of legal uncertainty, as well as broader riskrelated concerns. Accordingly, under public regulatory pressure and the threat of intervention the industry, spearheaded by ISDA, undertook to reduce confirmations backlogs, particularly through increased automation processes. By 2007 the industry had largely achieved this across many product classes, including in credit derivatives. ${ }^{121}$

While acknowledging industry efforts with respect to trade 'compression', the PWG harboured concerns that market participants had not achieved a 'steady state'; noting unnerving spikes in backlogs of unconfirmed trades in credit derivatives in July and August 2007. ${ }^{122}$ The PWG also outlined its broader reservations in relation to industry settlement processes for CDS. Prior to the GFC, CDS market participants retained a degree of flexibility as to how exactly a contract could be settled upon the occurrence of a triggering 'credit event'. Market participants could decide on a case-by-case basis as to whether they preferred 'physical settlement', requiring protection buyers to actually deliver defaulted securities to the protection seller in return for CDS payout, or traditional 'cash settlement'. ISDA had developed a 'voluntary auction protocol' prior to the GFC seeking to streamline cash settlement processes but it had not been adopted industry-wide at the onset of the GFC.

Such divergences in settlement processes presented a particular problem for systemically important dealer banks ${ }^{123}$ acting as market-makers in CDS transactions. Dealers attempting to ensure that their intermediated transactions were 'offsetting' from a risk-management perspective could be fatally

\footnotetext{
${ }^{118}$ Comprising the US Department of the Treasury, Board of Governors of the Federal Reserve System, Securities and Exchange Commission and Commodity Futures Trading Commission.

${ }^{119}$ US Treasury, Policy Statement on Financial Market Developments: The President's Working Group on Financial Markets (13 March 2008): available at http://www.treasury.gov/resource-center/finmkts/Documents/pwgpolicystatemktturmoil 03122008.pdf (hereinafter 'PWG Report').

${ }^{120}$ D. Duffie, T. Lubke and A. Li, Policy Perspectives on OTC Derivatives Market Infrastructure (Milton Friedman Institute for Economics Working Paper No. 2010-002, January 2010): available at http://papers.ssrn.com/sol3/papers.cfm?abstract id=1534981

${ }^{121}$ See, e.g., S. Listokin-Smith, Meta-Regulation of OTC Derivatives Contracts Post Reform (Working Paper, November 2009): available at http://papers.ssrn.com/sol3/papers.cfm?abstract id=1499964

${ }^{122}$ PWG Report above n. 119, p. 19.

${ }^{123}$ On the modalities of dealer failure see, e.g., D. Duffie, 'The Failure Mechanics of Dealer Banks' (2010) 24 Journal of Economic Perspectives 51.
} 
undermined if transactions were not settling in a consistent manner. ${ }^{124}$ In the midst of fraught conditions in early 2008, the PWG was thus concerned about 'the market impact such choices could have if multiple credit events were to occur simultaneously'. ${ }^{125}$ Therefore, in the broader context of standardisation and preparations for increased central clearing of derivatives the PWG recommended that:

'Supervisors should urge the industry to promptly amend standard credit derivative trade documentation to provide for cash settlement of obligations stemming from a credit event, in accordance with the terms of the cash settlement protocol that has been developed but not yet incorporated into standard documentation'. ${ }^{126}$

On foot of this, as well as subsequent nudging by the OTC Derivatives Supervisors Group (ODSG), ${ }^{127}$ ISDA promulgated the 'Big Bang' and 'Small Bang' Protocols (hereinafter 'the Protocols'). The Protocols essentially aimed to 'hardwire' the 'auction mechanism' into CDS contracts in order to ensure standardised cash settlement and interpretation processes. ${ }^{128}$ The saliency of new interpretation processes under the Protocols is of particular interest for the purposes of this chapter.

Prior to the Protocols, divergences in settlement patterns were not the only concerns for policy makers. Disagreements between counterparties as to whether a triggering event had occurred in the first place also stoked legal, as well as economic, risk and occasionally prompted litigation; for instance following a debt restructuring exercise by Argentina in the early $2000 \mathrm{~s} .{ }^{129}$ Therefore, in conjunction with streamlined settlement processes, ISDA's contractual Protocols also established centralised dedicated bodies which are responsible for issuing decisions as to whether triggering events have or have not occurred for the purposes of relevant CDS contracts. These bodies are known as the Credit Derivatives Determinations Committees (DCs).

b) Mechanics of the ISDA Credit Derivatives Determinations Committees

The DCs are governed by rules drawn up by ISDA, aspects of which are periodically updated to reflect emerging market trends or demands. ${ }^{130}$ There are five regional DCs. ${ }^{131}$ ISDA acts as a nonvoting secretary to all of them. Hence, strictly speaking there is a distinction between the DCs and ISDA itself, though as has been observed elsewhere: 'assuming the process works as advertised, DC decisions over time should track ISDA preferences'. ${ }^{132}$

\footnotetext{
${ }^{124}$ ISDA, The ISDA Credit Derivatives Determinations Committees (May 2012): available at http://dc.isda.org/

${ }^{125}$ PWG Report above n. 119, p. 19.

126 Ibid.

${ }^{127}$ Under the coordination of the US Federal Reserve Bank of New York (FNY) and also comprising the US Federal Reserve Bank of Richmond, Office of the Comptroller of the Currency, New York State Banking Department, Connecticut State Banking Department, Federal Deposit Insurance Corporation, Commodity Futures Trading Commission, Securities and Exchange Commission, French Prudential Supervisory Authority, German Federal Financial Supervisory Authority, Japanese Financial Services Agency, Swiss Financial Market Supervisory Authority and UK Financial Services Authority (now restructured):

http://www.newyorkfed.org/markets/otc derivatives supervisors group.html

${ }^{128}$ ISDA, Auction Hardwiring: available at http://www.isda.org/companies/auctionhardwiring/auctionhardwiring.html

${ }^{129}$ See, e.g., S. Choi and M. Gulati, 'Contract as Statute' (2006) 104 Michigan Law Review 1129.

130 ISDA, DC Rules: available at http://www.isda.org/credit/revisedcrules.html

${ }^{131}$ Americas, Asia excluding Japan, Australia-New Zealand, Europe and Japan.

${ }^{132}$ A. Gelpern and M. Gulati, 'CDS Zombies' (2012) 13 European Business Organization Law Review 347, at 363.
} 
The DCs are composed of ten voting derivatives dealers and five voting non-dealers serving on rotation, as well as two non-voting consultative dealers and two non-voting consultative nondealers. Central clearinghouses (CCPs) have also been afforded 'observer' status on the DCs. ${ }^{133}$ Membership of the DCs is reviewed annually. ${ }^{134}$ Dealer membership is contingent on aggregate CDS trading volumes both globally and in the geographical market of the relevant $\mathrm{DC}$, with reference to market data registered with Depository Trust Clearing Corporation (DTCC). ${ }^{135}$ Non-dealer members are selected on the basis of their size.

Membership of each regional DC is on an 'institutional' rather than 'person-specific' basis. ISDA stresses that DC members are also expected to fully adhere to prevailing legal and regulatory obligations, for instance on insider trading and market manipulation. ${ }^{136}$ Fundamentally, the DCs are charged with adjudicating, ad-hoc, on standard questions ('Potential DC Issue') ${ }^{137}$ submitted to them by CDS market participants ('Eligible Market Participants' and 'Eligible CCPs'). These questions typically relate to whether a particular triggering event has occurred with respect to a reference entity (for instance a corporate or sovereign) in accordance with ISDA's Credit Derivatives Definitions and, if so, whether a settlement auction should be held; along with other auction-related modalities. It is necessary for a submitter ('Eligible Market Participant') to be party to a CDS contract incorporating the Protocols ('Relevant Transaction'). ${ }^{138}$ It is possible for questioners to shield their identity by submitting a so-called 'General Interest Question'. ${ }^{139}$

An ISDA DC can, inter alia, decline to consider requests which are deemed to purely relate to a bilateral dispute between two market participants. ${ }^{140}$ Most questions must be accepted by at least one DC Voting Member, ${ }^{141}$ which is intended to filter frivolous issues. Where votes proceed, they are taken on the basis of publicly available information ${ }^{142}$ and contingent upon whether a particular credit or restructuring event is deemed to have occurred in accordance with the relevant ISDA Credit Derivatives Definitions. The DCs are required to reach an 80 per cent supermajority in decisions. ${ }^{143}$ If a DC fails to reach such a majority on a particular question, or if it voluntarily elects on certain matters, a question may be referred to a panel of external reviewers. External review panels are drawn from a pool of lawyers, retired judges, academics and other experts who can hear legal arguments and issue a decision. ${ }^{144}$

DCs are not mandated to accompany their 'Yes' or 'No' decisions with detailed reasoning, though this is not precluded either. ${ }^{145}$ However, in August 2012 ISDA amended the DC Rules to facilitate the

\footnotetext{
${ }^{133}$ Sections 1.6-1.8, DC Rules above n. 130.

${ }^{134}$ See ISDA, ISDA Announces Annual Determinations Committees Outcome (28 March 2013): available at http://www2.isda.org/news/isda-announces-annual-determinations-committees-outcome0

${ }^{135}$ Section 1.3, DC Rules above n. 130.

${ }^{136}$ ISDA, DC Paper above n. 114.

${ }^{137}$ Section 2.1(a), DC Rules above n. 130.

${ }^{138}$ Section 1.1(a), DC Rules above n. 130.

${ }^{139}$ Section 2.1(a), DC Rules above n. 130.

${ }^{140}$ Section 2.2(a), DC Rules above n. 130.

141 Ibid.

${ }^{142}$ Section 2.1(b) and 3.1(a), DC Rules above n. 130.

${ }^{143}$ Section 2.3(a), DC Rules above n. 130.

${ }^{144}$ See, generally, Section 4, DC Rules above n. 130.

${ }^{145}$ Section 2.5(v), DC Rules above n. 130.
} 
publication of a summary 'Meeting Statement', ${ }^{146}$ though the informational value of these statements may vary somewhat from case to case. ${ }^{147}$ Nonetheless, external review panels are seemingly expected to prepare a summary and analysis of their decisions and for these to be published by ISDA, ${ }^{148}$ though it is worth noting that the external review process is rarely invoked.

c) Private Governance, Public Implications: The Regulatory and Normative Salience of the DCs

The establishment of the DCs presents an interesting case study given that, in the final analysis, they emerged in response to pressures from public actors. In fact, the overall auction hardwiring process, of which the DCs form part, was explicitly welcomed by key public regulators. ${ }^{149}$ But, notwithstanding the potential for the DCs to exert third party effects (including for sovereigns), public actors did not demonstrate an interest in becoming involved in the DC process per se; thereby implicitly delegating that space to private self-regulation. ${ }^{150}$

The concentrated nature of the OTC derivative markets, particularly on the dealer bank side, is relevant in attempting to contextualise the DCs. A theory put forth by Daniel Mügge may be quite instructive in this respect. ${ }^{151}$ Mügge reasons that where industries become dominated by a group of 'producer' firms, particularly those which organise themselves through trade associations, they can, despite exogenous shocks, be well positioned to define aspects of regulatory reform agendas from the outset. Or, as Mügge puts it, 'suggest "solutions" to problems they themselves helped define'. ${ }^{152}$ Accordingly, where dominant firms are faced with regulatory overhaul they may be capable of successfully warding off public intervention in certain complex areas (in this case CDS determinations) by offering "'tightened" self-regulation in return for public "oversight". ${ }^{153}$

Through this, private actors can seek to construct a 'cognitive and political community, taking the role of the creator of the rules of the game'. ${ }^{154}$ However, the success of this endeavour can be uncertain. Huault and Rainelli-Le Montagner suggest that the creation of 'new rules of the game' in a technical market (such as OTC derivatives) still might not 'be expected to favour the adhesion of other actors who feel technically handicapped and uncertain about the potential opportunism of a small group of active promoters' ${ }^{\prime 155}$ Predictably, the composition of, and powers assumed by, the

\footnotetext{
${ }^{146}$ [http://www2.isda.org/news/isda-publishes-amendments-to-the-credit-derivatives-determinationscommittees-rules-to-further-improve-transparency].

${ }^{147}$ Compare ISDA, Irish Bank Resolution Corporation Credit Event Determination (http://dc.isda.org/documents/2013/02/emea determinations committee decision 13022013 ibrc.pdf) and SNS Bank NV Credit Event Determination (http://dc.isda.org/documents/2013/02/emea_determinations committee decision_13022013-sns-2.pdf). ${ }^{148}$ Section 4.6(f), DC Rules above n. 130.

${ }^{149}$ OTC Derivatives Supervisors Group, New York Fed Welcomes CDS Auction Hardwiring (12 March 2009): available at http://www.newyorkfed.org/newsevents/news/markets/2009/ma090312.html

${ }^{150}$ It could perhaps be suggested that this represented a 'regulatory licence' bestowed on ISDA by public actors. On the concept of regulatory licenses see F. Partnoy, The Siskel and Ebert of Financial Markets: Two Thumbs Down for the Credit Rating Agencies' (1999) 77 Washington University Law Quarterly 619.

${ }^{151}$ D. Mügge, 'Private-Public Puzzles: Inter-firm Competition and Transnational Private Regulation' (2006) 11 New Political Economy 177.

152 Ibid, at 185.

153 Ibid.

${ }^{154}$ I. Huault and H. Rainelli-Le Montagner, 'Market Shaping as an Answer to Ambiguities: The Case of Credit Derivatives' (2009) 30 Organization Studies 549, at 567.

155 Ibid.
} 
DCs provoked debate in certain quarters from the outset. In particular, the potential for conflicts of interest on the DCs attracted comment. A senior individual at a major international law firm summed up the challenge facing the DCs as follows:

'The $\mathrm{DC}$ is new, so any time there is a grey area you're going to get tension between dealers and buy side. But the DC has helped bring some certainty to the process, and it's a massive improvement on each individual party making its own decision and people holding off in the market to see what others $\mathrm{do}^{\prime} .{ }^{156}$

Another derivative market participant has observed:

'It's fair to say there is a concern that somebody might be biased towards their book, but in reality it's 15 firms making the decision, and the net effect tends to be pretty neutral. If someone's arguing something clearly biased, they'll lose all credibility. People know there is a huge public and regulatory focus on the DC, and no one wants to be that person'. ${ }^{157}$

ISDA itself has also mounted a defence of the DCs on the basis that the vast majority of questions considered by the DCs are technical, straightforward and efficiently settled; that the 80 per cent supermajority mitigates conflicts of interests; and DC members are, in any event, obligated to observe relevant public regulations, such as anti-manipulation provisions. On the face of it, ISDA's contentions carry merit insofar as the vast majority of the determinations issued by the DCs do seem to attract little or no public comment or interest. Aside from this, market participants have also questioned what other alternative structure could be viable, as expressed in the following terms:

'If you want a product that everyone can trade that isn't reliant on bilateral triggers then you need a public committee. And it makes sense for the people most interested in the product to be on that'. ${ }^{158}$

Others have been considerably less charitable regarding the DC mechanism. For instance, Lisa Pollack, writing for the Financial Times, observed the following at the height of the DC for Europe's lengthy deliberations as to whether a CDS credit event occurred following the nationalisation of Dutch institution SNS Reaal: ${ }^{159}$

'These guys can vote however they wish, it's not that they are subject to any law other than that which they set for themselves (hush, hush now, financial stability is safe with them)...unlike the real, legal, world, the committee members are not obligated to abide by any precedents they set. So the concern about going against previous decisions is a question of fashion alone' ${ }^{160}$

Aside from this ongoing debate regarding the efficiency and predictability of the DC mechanism, there have clearly been instances where DC determinations, as well as the background dynamics of those determinations, have triggered a wider public interest and exerted identifiable third party effects. This has especially been the case in relation to determinations which have involved more complex questions and, in particular, where the reference entity has been a sovereign or a publicly

\footnotetext{
${ }^{156}$ C. Whittall, 'IFR - Defending the ISDA Determinations Committee', Reuters (8 August 2011): available at http://uk.reuters.com/article/2011/08/08/derivatives-isda-dc-ifr-idUKL6E7J812720110808

${ }^{157}$ C. Whittall, 'Dealers Defend Committee's Record as Restructuring Event Put in Play', International Financing Law Review (5 August 2011): available at http://www.ifre.com/dealers-defend-isda-committees-record-asrestructuring-event-put-in-play/648065.article 158 Ibid.

${ }^{159}$ See ISDA, Credit Event: SNS Bank NV: available at http://dc.isda.org/cds/sns-bank-nv/ .

${ }^{160}$ L. Pollack, 'The Non-Precedent-Setting, Own Law-Making, Secretive CDS Committee is having a Seriously Bad Month', Financial Times (13 February 2013).
} 
supported financial institution. In these cases it is evident that determinations of the ISDA DCs can be 'socially significant'.

\section{i) Greece}

Perhaps one of the most controversial and high profile recent examples of a DC becoming embroiled in an event of public interest was in the context of the 'quasi-voluntary' Greek sovereign debt restructuring exercise with private creditors ${ }^{161}$ which came to a head in March 2012. ${ }^{162}$ Given the relative opacity and size of the CDS markets, and resulting interconnectedness amongst systemically important participants, the public policy dilemma was stark. ${ }^{163}$ And it quickly became clear to public policy makers and CDS market participants alike that the DC for Europe occupied a pivotal position in this saga. Ultimately, in March 2012 and following the activation of retroactive collection action clauses (CACs) ${ }^{164}$ by the Greek authorities (binding private creditors holding Greek law-governed bonds) the DC for Europe determined that a restructuring credit event had occurred for the purposes of Greek CDS's. ${ }^{165}$ But, as Anna Gelpern and Mitu Gulati have illustrated, ${ }^{166}$ this determination appears to have been preceded by a considerable degree of background jockeying amongst public and private stakeholders, leading to periods of uncertainty and intriguing incidents, worth exploring here.

In July 2011, at an earlier stage in negotiations on this restructuring exercise, ISDA published a 'Greek Sovereign Debt Q\&A' on its website which, inter alia, explained the DC process as well as the usual criteria for a restructuring credit event to occur. By way of a further update issued in October 2011 ISDA suggested that, while it was premature for a DC determination on the matter, it appeared to ISDA that the terms of a potential restructuring which were being discussed at that particular time were unlikely to constitute a 'restructuring credit event' triggering CDS contracts. ${ }^{167}$ Gelpern and Gulati have branded this intervention 'extraordinary' in the circumstances and venture that it 'could not have been made without consulting with - perhaps even some prodding from - at least some of the [ISDA] membership, European officials, and outside counsel called upon to advise the DCs'. ${ }^{168}$

Subsequently, with fears that European Central Bank (ECB) and Eurosystem-held Greek bonds could be dragged into the emerging debt restructuring arrangement, February 2012 saw Greece swap central bank-held bonds for new ones, which only differed in their identification numbers. The ultimate objective was to ensure that these new identification numbers could be omitted from the

\footnotetext{
${ }^{161}$ Represented by another powerful financial association, the Institute of International Finance (IIF): http://www.iif.com/

${ }^{162}$ See, e.g., J. Zettlemeyer, C. Trebesch and M. Gulati, The Greek Debt Exchange: An Autopsy (Duke University Faculty of Law Working Paper, September 2012): available at http://scholarship.law.duke.edu/cgi/viewcontent.cgi?article=5343\&context=faculty scholarship

${ }^{163}$ Gelpern and Gulati above n. 132, at 370.

${ }^{164}$ For general discussion of CACs see, e.g., M. Gulati and L. C. Buchheit, 'Drafting a Model Collective Action Clause for the Eurozone' (2011) 6 Capital Markets Law Journal 317.

${ }^{165}$ See ISDA, Credit Event: The Hellenic Republic (9 March 2012): available at http://dc.isda.org/cds/thehellenic-republic-3/

${ }^{166}$ Gelpern and Gulati above n. 132.

${ }^{167}$ ISDA, Greek Sovereign CDS: available at http://www2.isda.org/greek-sovereign-cds/

${ }^{168}$ Gelpern and Gulati above n. 132, at 374.
} 
list of instruments which might be subject to the restructuring exercise ('haircut'). ${ }^{169}$ However, the DC for Europe was petitioned for a determination as to whether this ostensibly nifty exercise effectively amounted to 'subordination' of other Greek creditors and, thus, whether it was a CDStriggering restructuring credit event. On 1 March 2012 the DC for Europe unanimously responded in the negative because, as far as it was concerned, the 'specific fact pattern...does not satisfy either limb of the definition of Subordination as set out in the ISDA 2003 Credit Derivatives Definitions'. ${ }^{170}$

This was not the first time the DC for Europe was asked to consider a potential subordination in the context of sovereign distress. Such a question had, for instance, arisen in 2011 in the wake of International Monetary Fund (IMF) financial assistance to Ireland (albeit in the context of a different fact pattern). ${ }^{171}$ The posture of the DC in the Greek case has been deemed by Gelpern and Gulati to be 'defensible' in a technical sense. However, they also contend that, in a practical sense, 'no one with even a passing knowledge of the situation had any doubt that the only rationale for the ECB swap was to treat its bonds better than those held by private creditors'. ${ }^{172}$ In that same determination, the $D C$ also confirmed that the passage of Greek legislation retroactively amending Greek law-governed bonds to insert CACs did not, in and of itself, amount to a restructuring credit event. This also caused consternation in certain quarters, which was acknowledged by the manager of a hedge fund which actually sat on the DC. He commented immediately afterwards: 'If I were a buyer of protection on Greece and have [sic] seen the result this morning in terms of no protection, then I would be upset'. ${ }^{173}$

In any event, the Greek authorities did subsequently activate the CACs and the DC for Europe duly confirmed on 9 March 2012 that this activation constituted a CDS-triggering restructuring credit event. An auction would subsequently be held to settle the CDS obligations ${ }^{174}$ which turned out to be less problematic than was perhaps initially feared; ${ }^{175}$ though, nonetheless, given the controversy around certain aspects of the Greek event ISDA has since proposed certain revisions to its Credit Derivatives Definitions. ${ }^{176}$

More generally, the Greek CDS event and background manoeuvrings carried clear implications for third party stakeholders and fuelled concerns amongst certain market participants regarding the appropriateness of the DC mechanism in these instances. The general challenge was summed up by one derivatives lawyer as follows:

\footnotetext{
${ }^{169}$ Gelpern and Gulati above n. 132, at 378-380.

170 ISDA, Credit Event: The Hellenic Republic (1 March 2012): available at http://dc.isda.org/cds/the-hellenicrepublic-2/

${ }^{171}$ See ISDA, Credit Event: Republic of Ireland (15 March 2011): available at http://dc.isda.org/cds/republic-ofireland/

${ }^{172}$ Gelpern and Gulati above n. 132, at 380.

${ }^{173}$ S. Forgione, 'Greek Debt Ruling Dangerous Precedent: PIMCO's Gross', Reuters (1 March 2012): available at http://www.reuters.com/article/2012/03/01/us-greece-bonds-pimco-idUSTRE8201D920120301

${ }^{174}$ For discussion see Zettlemeyer, Trebesch and Gulati above n. 161.

${ }^{175}$ See, e.g., A. Moses, 'Greek Swaps Sellers to Pay \$2.5 Billion to Settle Contracts', Bloomberg (19 March 2012): available at http://www.bloomberg.com/news/2012-03-19/greek-bonds-get-final-value-of-21-5-indefault-swaps-auction.html

${ }^{176}$ See, e.g., ISDA, 2003 ISDA Credit Derivatives Definitions - Note on Implementation Timing Proposal and Key Changes [http://www2.isda.org/news].
} 
'Some people are certainly concerned they're being manipulated by the dealers...On technical points, the $D C$ is fine. The problem is for larger decisions like Greece...It's not a perfect mechanism for big issues that affect a large amount of people to be decided by a small portion of the overall market'. ${ }^{177}$

As has also been observed in an IOSCO report, while the sovereign CDS markets survived the Greek event it 'brought to the forefront several doubts on the future of this market'. ${ }^{178}$ Additionally, in the immediate term this determination triggered socially significant ripples further afield.

ii) KA Finanz

A little known Austrian 'bad bank', KA Finanz had been siphoned off from Kommunalkredit Austria following its nationalisation by the Austrian Government in October 2008. ${ }^{179} \mathrm{KA}$ Finanz houses the securities and CDS portfolio remaining in the wake of this demerger and has been charged with its 'structured rundown'. ${ }^{180}$ Following the Greek restructuring and determination of the ISDA DC on 9 March 2012 KA Finanz issued a statement indicating that it would require further public funding support to cover its positions in Greek securities and CDS contracts. ${ }^{181}$ In its interim results for 2012 KA Finanz (KF) thus confirmed:

'The debt restructuring measures for the Republic of Greece implemented in the first quarter of 2012 had a significant impact on KF...which could not be covered by KF's capital base. To recapitalise KF, comprehensive capital measures, effective as of 31 December 2011, were agreed upon with the Republic of Austria.... 182

Accordingly, KA Finanz illustrated how the impact of a DC determination could, due to the embedded legal significance of the Protocols across the CDS markets, directly affect a third party (i.e. the Austrian Government) and carry with it distributional implications. This is significant because, although the DCs can exert such third party effects, it does not necessarily follow that affected third parties have a right to input into the DC process. Put differently, despite the fact that a DC determination could negatively affect a failed bank under the Austrian Government's (public) oversight (i.e. KA Finanz), the Austrian Government itself was not entitled to appear before the DC; should it theoretically have wished to attempt to influence the DC determination on Greek CDS from the outset. Nor was the Austrian Government entitled to appeal against the DC determination triggering Greek CDS, in comparison to a potential right of appeal against a decision of a court of law.

\footnotetext{
${ }^{177}$ Whittall above n. 156.

${ }^{178}$ IOSCO above n. 21, p. 18.

${ }^{179}$ B. Groendahl, 'Austria's Government Decides to Sell Nationalized Lender Kommunalkredit', Bloomberg (29 November 2011): available at http://www.bloomberg.com/news/2011-11-29/austrian-government-to-startsale-of-nationalized-lender-kommunalkredit.html

${ }^{180}$ KA Finanz AG, About us: available at http://www.kafinanz.at/EN/About\%20us/About+us.aspx

${ }^{181}$ KA Finanz AG, Private Sector Involvement - Greece (9 March 2012): available at http://www.kafinanz.at/uploads/Adhoc Griechenland KF en 604 EN.pdf; Z. Schneeweiss \& B. Groendahl, 'Austria Faces \$1.3 Billion Bank Injection After ISDA Triggers Greek CDS', Bloomberg (9 March 2012): available at http://www.bloomberg.com/news/2012-03-09/austria-faces-1-3-billion-bank-injection-after-isda-triggersgreek-cds.html.

182 KA Finanz AG, Interim Result 2012 of KA Finanz AG (3 August 2012): available at http://www.kafinanz.at/uploads/PA Halbjahresbilanz2012_KF_en final 618 EN.pdf
} 
Therefore, KA Finanz was arguably illustrative of the fact that a DC decision can exert third party (distributional) implications for a range of stakeholders; including government actors which themselves may have little, or no, direct proximity to the DC process itself. In that sense, it could be posited that certain DC determinations can be 'socially significant'.

However, third party effects were not confined to the Greek event. Previous determinations can similarly be considered to have carried implications for public policy makers, as well as other challenges. An apt example was Bradford \& Bingley.

iii) Bradford \& Bingley

Coleen Baker has highlighted the case of Bradford \& Bingley (B\&B), a UK mortgage lender, which was nationalised by the UK Government in September 2008. As part of their strategy to deal with B\&B, the UK authorities permitted B\&B to defer meeting obligations on subordinated bonds. Such a course of action would not, in the view of the UK authorities, constitute a credit event which could frustrate B\&B's repayment of rescue funds received from the UK authorities. ${ }^{183}$ However, Morgan Stanley queried this with the DC for Europe which determined that a 'failure to pay' credit event had in fact occurred for the purposes of CDS contracts referencing B\&B bonds, in accordance with ISDA's Credit Derivatives Definitions. ${ }^{184}$ Baker brands this a 'powerful example of the development of global private governance mechanisms and their potential impact on government actors'. ${ }^{185}$ Of further interest, in this case the petitioner (Morgan Stanley) ${ }^{186}$ also sat on the relevant DC and voted in favour of calling a credit event; arguably raising broader questions over whether it is appropriate for a questioner who may have a vested interest in a particular determination to actually sit on the panel issuing that determination.

Overall, these selected events at least demonstrate that the DCs wield significant power to adjudicate on systemically important events in the financial markets; some with potentially public implications. Consequently, it is warranted to consider future prospects for the DCs in the context of wider regulatory reforms in the OTC derivatives markets.

\section{Walking the Tightrope of Regulatory Reform}

In the wake of the GFC, public authorities across major trading jurisdictions have instigated significant overhaul of OTC derivative markets ${ }^{187}$; essentially with the objective of emulating key infrastructure already prevailing in the exchange-traded (ET) derivatives markets. With a view to mitigating risk and increasing transparency, an increased proportion of OTC derivatives will, where appropriate ${ }^{188}$, be channelled through central clearinghouses (CCPs) and/or traded on exchanges or

\footnotetext{
${ }^{183}$ C.M. Baker, 'Regulating the Invisible: The Case of Over-the-Counter Derivatives' (2010) 85 Notre Dame Law Review 1287.

${ }^{184}$ ISDA, Credit Event: Bradford \& Bingley: available at http://dc.isda.org/cds/bradford-bingley-plc/

${ }^{185}$ Baker above n. 182 at 1361.

${ }^{186}$ R. Khasawneh, 'ISDA Unanimous in Bradford \& Bingley CDS “Default" Vote', eFinancialNews (9 July 2009): available at http://www.efinancialnews.com/story/2009-07-09/isda-unanimous-in-bradford-and-bingley-cdsdefault-vote as cited in Baker above n. 182.

${ }^{187}$ See, e.g., G. Morgan, 'Reforming OTC Markets: The Politics and Economics of Technical Fixes' (2012) 13 European Business Organization Law Review 391.

${ }^{188}$ For instance, liquidity and legal standardisation will be relevant factors in determining the clearing and exchange-trading-eligibility of instruments.
} 
electronic platforms. OTC derivatives will also be reported to central trade registries and/or public authorities. Implementation of this prescription is already well underway in certain jurisdictions, particularly in the US. ${ }^{189}$ But a question arises as to precisely what role the DCs will continue to play in an environment where certain previously privately and bilaterally traded ISDA-governed CDS contracts will now be clearing through CCPs.

Basically, central clearinghouses (CCPs) are entities which stand in the middle of OTC derivative transactions and thereby become the counterparty to each market participant using their services. CCPs aim to ensure prudent risk management of trades, as well as smooth post-trade settlement. CCPs will aim to mitigate risks by ensuring that contracts are, for instance, offsetting and making use of 'multilateral netting'. ${ }^{190} \mathrm{CCPs}$ are systemically important in their own right and sensitive to the failure of their members. Therefore, in order to underpin their own viability CCPs will thus demand that their members adhere to certain membership criteria. ${ }^{191}$

As has been highlighted by Joanne Braithwaite, post-reform contractual arrangements in the OTC derivatives markets are therefore likely to differ somewhat depending on the status of the instruments and market participants in question. ${ }^{192}$ If a contract is clearable (or legally subject to the clearing obligation) and both counterparties are members of a relevant clearinghouse (i.e. are 'clearing members'), such instruments and post-trade arrangements are likely to be largely governed from the outset by the standard terms and rules of a particular CCP (which may not necessarily emulate ISDA contract terms). ${ }^{193}$

However, due to the nature of CCP membership criteria and/or the precise implementation of the clearing prescription across jurisdictions, not all market participants will be full clearing members and many may need to engage in so-called 'indirect clearing'; in other words channel their trade through a market participant who is a full clearing member of a CCP. In this case, it seems possible that two contracts may exist, one between the client and the clearing member and another between the clearing member and the CCP. ${ }^{194}$ The first arrangement (i.e. between the client and the clearing member) could continue to be largely predicated on the ISDA Master Agreement and/or perhaps with some role for other contractual mechanisms; such as the ISDA-Futures Industry Association

\footnotetext{
${ }^{189}$ See, e.g., FSB, OTC Derivatives Market Reforms: Fifth Progress Report on Implementation (15 April 2013): available at $\mathrm{http}: / / \mathrm{www}$.financialstabilityboard.org/publications/r 130415.pdf

${ }^{190}$ See, e.g., S.G. Ceccheti, J. Gyntelberg and M. Hollanders, 'Central Counterparties for Over-the-Counter Derivatives', Bank for International Settlements Quarterly Review (September 2009); E. Ledrut and C. Upper, 'Changing Post-Trading Arrangements for OTC Derivatives' (December 2007) Bank for International Settlements Quarterly Review 83.

${ }^{191}$ For further discussion of the CCP prescription see, e.g., C. Pirrong, The Economics of Central Clearing: Theory and Practice (ISDA Discussion Paper Series No. 1, May 2011): available at http://www2.isda.org/functional-areas/research/discussion-papers/; J.P Braithwaite, 'The Inherent Limits of "Legal Devices": Lessons for the Public Sector's Central Counterparty Prescription for the OTC Derivatives Markets' (2011) 12 European Business Organization Law Review 87.

192 See J.P. Braithwaite, 'OTC Derivatives, the Courts and Regulatory Reform' (2012) 7 Capital Markets Law Journal 364, at 374-378.

193 Ibid., at 375-376.

194 Ibid.
} 
(FIA) Cleared Derivatives Execution Agreement. ${ }^{195}$ The engagement between the clearing member and the CCP could be governed by the CCP's own standard terms. ${ }^{196}$

A substantial number of contracts will also not be clearing-eligible under public regulatory reforms and, although subject to increased capital and risk management (e.g. collateralisation) requirements, will continue to be traded privately and bilaterally under the ISDA Master Agreement. Specifically in relation to credit derivatives, including CDS, it seems likely at time of writing that a considerable number of these contracts will continue to be traded in this space. ${ }^{197}$ In fact, ISDA has suggested that a significant proportion of CDS contracts, including 'single-name' CDS, will not be eligible for central clearing. ${ }^{198}$

Accordingly, there is little reason to suspect that non-cleared CDS will not continue to be governed by prevailing ISDA documentation and processes, including the DC mechanism. And it also seems likely that certain CDS contracts subject to a clearing obligation could, in theory at least, be governed by key aspects of the DC mechanism; if not by ISDA-inspired documentation and definitions more generally. This perspective is supported by the fact that CCPs have been co-opted onto certain ISDA DCs; albeit as observers. ${ }^{199}$ ISDA has also published amendments to its rules enabling CCPs to explicitly afford the DCs jurisdiction over cleared CDS. ${ }^{200}$ Taken together and despite broader market infrastructure reforms, these factors suggest that the ISDA DCs are likely to wield significant influence outside, and possibly within, clearing processes.

Therefore, the ISDA DCs may continue to occupy a sensitive position in the financial markets. But this will also arguably force them to walk a somewhat precarious tightrope in the context of broader public regulatory reforms. On the one hand, ISDA may be anxious to maintain as much 'regulatory share ${ }^{201}$ as possible, while on the other avoid raising the hackles of public policy makers. However, as the Greek crisis has demonstrated, public threats to ISDA's power may flare up from time to time, particularly in cases involving sovereigns which trigger a broader interest. ${ }^{202}$ Additionally, as has been demonstrated in other contexts, such as the interbank rate-setting controversy, socially important private governance arrangements are susceptible to public intervention in the event of perceived failures. ${ }^{203}$ Indeed, by time of writing ISDA itself had been drawn into this controversy by

\footnotetext{
${ }^{195}$ FIA, FIA-ISDA Cleared Execution Agreement: available at http://www.futuresindustry.org/fiaisda-clearedderivatives-execution-agreement-.asp

${ }^{196}$ Braithwaite above n. 189 , at 377.

${ }^{197}$ See, e.g., Financial Stability Board, OTC Derivatives Market Reforms: Fourth Progress Report on Implementation (31 October 2012) pp. 60-61: available at http://www.financialstabilityboard.org/publications/r 121031a.pdf

198 ISDA above n. 97.

199 ISDA, ISDA Announced Annual Determinations Committees Outcome (28 March 2013): available at: http://www2.isda.org/news/isda-announces-annual-determinations-committees-outcome0

${ }^{200}$ ISDA, Amendments to the ISDA Credit Derivatives Determinations Rules with Respect to Cleared Reference Entities (9 September 2012): available at http://www.isda.org/credit/revisedcrules.html

${ }^{201}$ Black above n. 117.

202 Gelpern and Gulati above n. 132.

${ }^{203}$ See, e.g., European Commission, Statement by Commissioner Michel Barnier on Interbank Interest Rate Benchmarks (8 February 2013): available at http://europa.eu/rapid/press-release MEMO-13-82 en.htm; UK Treasury, The Wheatley Review: available at http://www.hm-treasury.gov.uk/wheatley review.htm
} 
virtue of a public regulatory investigation into ISDA's own (hitherto little known) derivatives benchmark rate ('ISDAFIX'). ${ }^{204}$

The ISDA DCs will presumably be conscious that public intervention is a threat and thus remain cognisant of their potential influence and associated responsibilities. At time of writing public policy makers have not indicated that they are inclined to interfere with the DC process. Nonetheless, certain issues around third party implications and potential conflicts of interest may continue to haunt the DCs. As such, in the longer term it may be desirable for all stakeholders to consider the merits of further reform of overall institutional governance in these markets, as has already been proposed elsewhere. ${ }^{205}$

\section{Conclusions}

Regulatory arrangements for the OTC derivatives market serve to demonstrate the resilience of transnational private regulation, in a transnational business governance interactions (TBGI) environment subject both to the significant external shock of the global financial crisis, and intense pressure on governmental actors to demonstrate that they are acting effectively to reduce or eliminate the kinds of risk which created a global financial meltdown. ${ }^{206}$ How can such resilience be explained? It is not credible to think that policy makers might continue to think of OTC derivatives as a purely technical area, in which regulatory decision making at worst affects only bilateral interests of parties to transactions. The third party effects of the way in which contracts are written, the protections granted by legislation, and also the decisions of the Credit Derivatives Determinations Committees (DCs) are of great potential significance in a wide range of transactions. The lack of transparency associated with private arrangements and their impact has been a particular source of criticism. ${ }^{207}$

An alternative explanation for the continuing acceptance of ISDA is, recognising the effects on interests, that a judgement has been made which affords priority to the expertise of those practitioners involved, and which is accepting of the mechanisms through which no one set of interests (whether individual, for example of a particular bank, or collective, for example of banks as a whole) is able to dominate decisions. There is an implicit delegation of power to make decisions of potentially great significance, but which in most cases secure little attention.

In this case of TBGI between state and non-state actors, these occur in both operational and policy spheres. Operationally there is a strong stake for governments both directly in relation to determinations concerned with sovereign debt and indirectly in addressing fall-out, for example to

\footnotetext{
${ }^{204}$ See, e.g., M. Leising, L. Fortado and J. Brunsden, 'Meet ISDAfix, the Libor Scandal's Sequel', Bloomberg (18 April 2013): available at http://www.businessweek.com/articles/2013-04-18/meet-isdafix-the-libor-scandalssequel; ISDA, ISDAFIX: available at http://www2.isda.org/asset-classes/interest-rates-derivatives/isdafix/

${ }^{205}$ See, e.g., K.N. Johnson, 'Things Fall Apart: Regulating the Credit Default Swap Commons' (2011) 82 University of Colorado Law Review 167, at 212-214; Baker above n. 168; D. Awrey, 'The Dynamics of OTC Derivatives Regulation: Bridging the Public-Private Divide' (2010) 11 European Business Organization Law Review 155.

${ }^{206}$ C. Scott, 'Regulating in Global Regimes' in Elgar Handbook of Regulation, ed. D. Levi-Faur (Cheltenham: Edward Elgar, 2012).

${ }^{207}$ S. Picciotto, Regulating Global Corporate Capitalism (Cambridge: Cambridge University Press, 2011) p. 270.
} 
banks and sovereigns, arising from sovereign debt decisions. There is also a regulatory dimension to operational relationships, as decisions about CDS instruments affect public regulatory issues, such as compliance by banks and others with capital adequacy and other prudential requirements.

At a policy level, interactions are concerned with the nature and extent of delegation to private governance institutions generally (including in this sphere not only ISDA and other trade associations, but also credit rating agencies, whose decisions affect creditworthiness and feed into public regulatory decision making), and to ISDA in particular. The delegation to ISDA over credit determinations is implicit, as if the structure has been thrown up as part of the market mechanism, requiring of intervention only where justified by market failure.

Whilst continuing events associated with the global financial crisis (GFC) encourage stronger scrutiny by national and supranational governmental bodies of private governance arrangements such as ISDA, it is striking how embedded private governance arrangements remain. Indeed, the crisis was a key factor in further crystallising ISDA's role through the systemization of CDS determinations, as it became increasingly important for such decisions to be made on a centralised basis, rather than on a bilateral and ad hoc basis. It is not clear that governmental actors would necessarily bring either greater legitimacy or expertise to the general task of the DCs. At the same time, whilst the function remains privately organised, it is nonetheless capable of exerting 'socially significant' third party effects in certain circumstances. This may continue to raise certain legitimacy and transparency issues, especially in cases where sovereigns and publicly supported financial institutions are at issue.

As a private actor at the centre of a regulatory regime with significant features of TBGI, ISDA comes across as a survivor, able to adapt itself to changing conditions, external shocks and challenges to the legitimacy of private regulation engendered by the GFC. This characteristic, above all, perhaps demonstrates the essentially political character of such private governance arrangements, even where key private regulators may protest that their roles are primarily technical. ${ }^{208}$

\footnotetext{
${ }^{208}$ T.Büthe, and W. Mattli. The New Global Rulers: The Privatization of Regulation in the World Economy (Princeton, NJ: Princeton University Press, 2011).
} 